\title{
The effects of The geomorphology and geologic parent materials on the natural environment assessment in the Burdur-Gölhisar basin, SW Anatolia
}

\author{
Burdur-Gölhisar havzasında (GB Anadolu) jeomorfoloji ve jeolojik ana materyalin doğal \\ ortam üzerine etkileri
}

İbrahim ATALAY ${ }^{1} \oplus$, Sevda ALTUNBAŞ² $\odot$, Muzaffer SILER $^{3} \odot$

${ }^{1}$ Karabük University, Department of Geography, Karabük, Turkey

${ }^{2}$ Akdeniz University, Department of Soil Sciences and Plant Nutriment, Antalya, Turkey

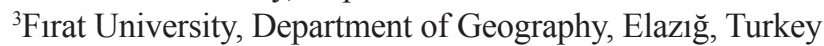

ORCID: İ.A. 0000-0002-0327-1485; S.A. 0000-0001-9779-9784; M.S. 0000-0001-5485-7008

\section{ABSTRACT}

Burdur-Gölhisar basin which is located in the western part of Lakes Region of Mediterranean region is found between the Menderes metamorphic masse and the eastern continuation of Taurus Mountain range. The present-day topography of this area was mainly formed by the vertical tectonic movements occurred between Middle Miocene and Last Pleistocene; the intensity of erosion and sedimentation processes have been controlled by not only fluvial process but also lithologic properties of parent materials. The basement of the study area is mainly composed of peridotite-serpentine that erupted and spread on the bottom of the Tethys Ocean. Clay-rich calcareous sediments forming limestones were accumulated on the peridotite-serpentine. They were emerged from the Tethys oceans as the result of tectonic movement occurred at the end of the Mesozoic era. The sandstone-conglomerate terrain was formed on the depression areas in the north-western part of the present-day Sögüt Mountains. The clayey and calcareous materials were accumulated in the neogene lake facies in the Burdur-Gölhisar basins. The main fault line passing in the east of the Burdur basin was rejuvenated six times. Thus, the faulted topography and erosion surfaces especially on marl deposit were developed according to the base level of the Burdur Basin and Gölhisar basins. The physical and chemical properties of the geologic parent materials have affected considerably soil formation and their physical and chemical traits. Namely, red Mediterranean soils (Alifsol/ Luvisol) have developed along the cracks and bedding surfaces of limestones on the sloping area and on the bottom of the karstic depression. The flat land lying between Gölhisar and Burdur Basins is the main spreading areas of chestnut soil (Mollisol). Rendzina soils have developed on the upper erosion surfaces on the marl deposit. The productive vegetation cover is found on the soft and inclined layered marl deposit, while poor vegetation cover is common on the compact and horizontally layered marl deposit. Sparse vegetation communities are seen on the exposed hard and partly weathered serpentine, whereas productive forest trees are found on the deeply weathered serpentine. At the same time, productive vegetation communities are common on the sandy soil developed on the sandstone and conglomerate. Vineyards, levanter and rose gardens are found on the dejection fan and dejection cones on the edges of the fault scarps in the Burdur Basin.

Keywords: Neotectonic, Soil Formation, Faulted Topography, Burdur-Gölhisar Basin. 


\section{INTRODUCTION}

Turkey which is found Alpine-Himalayan orogenic belt has very rugged and highland topography and almost all parent materials (bedrocks). After alpine orogenic movements present-day topography of Turkey has been shaped by the tectonic movements leading to the formation of pull-apart basin along the strike-slip fault zone and grabens-horst structure formed with vertical faulting movements (Atalay 2017). Intense erosion on the fault scarps and mountainous areas and intense erosion sedimentation occurring on the depressions resulted in the formation of different topographic-geomorphologic units. Each of geomorphic-topographic units and parent materials corresponds to distinctive ecological units in terms of soil formation, vegetation cover and agricultural activities and so on (Walter 1983; Bailey 1995a; 1995b; 1998; Atalay 2008; 2014; 2018c). For example, intrazonal soils reflecting the physical and chemical properties of the parent materials that exposed on the fault scarps and sloping areas are main occurrence areas of VII class land. The alluvial plain on the depression is the main agricultural production areas belonging to land class of III and IV. High ground water table in the lowest part of the depression is responsible for the formation of halobiome and hydrobiome on which VIII land capability class is found.

Burdur-Gölhisar basin which is the intermontane basin was formed mainly vertical tectonic movements occurred between middle Miocene and last Pleistocene period. In this area geomorphologic units and parent materials are the leading significant factors on the land capability classification and productivity of forest stands, agricultural products, land degradation and land-use activities. The fault scarp dissected "V" shaped valley on marl deposit is the main gully erosion areas. The erosion surfaces at an elevation of c. 1000, 1200 and $1300 \mathrm{~m}$ on the marl deposits are the main dry agricultural occurrence areas. The dejection fans and cones correspond to $\mathrm{V}$ class land on which some fruits are grown. Swamplands and lakes that are found closed lowlands are the main occurrence areas of hydromorphic alluvial and colluvial soils.

The geologic parent materials containing peridotite-serpentine, Mesozoic crystallized limestone, neogene marl on the sloping areas are the main occurrence areas of intrazonal soils reflecting physical and chemical properties of parent material effects. Serpentine in the flat land, for example, has produced fertile chestnut soil on which cereals are harvested. But outcropped serpentine on the sloping area has determined the growth rate of forest trees depending on weathering stages. The productive Anatolian black pines (Pinus nigra) forests are common on the deeply weathered serpentine in Taurus Mountains and in the SW Anatolia (Tetik and Yeşilkaya 1997; Atalay and Efe 2010; Atalay 2016a; Atalay et al., 2019).

The main aim of the study is to illuminate the effects of the geomorphologic units and parent material relationship on the natural environment properties such as plant distribution, land use, land capability classification in the Burdur-Gölhisar Basin (Fig. 1).

\section{MATERIAL AND METHOD}

During the field study carried out between 2017 and 2019 geological and geomorphological evolution was illuminated. Soil and parent material samples were taken to reveal the main physical and chemical properties of the parent materials and they analysed at the laboratories of department of Soil Science and Plant Nutrition, Akdeniz University and Forest Research Institute in İzmir. The factors affecting of the formation gully were examined during the field study.

This study makes use of geomorphological studies (Cohen and Erol 1969; Erol 1975; Atalay 1977; Atalay et al., 2017a, b, c, d; Atalay et al. 2018 and Altunbaş 2018; Altunbaş et al., 2019a, b) and physical study (Sungur 1974). The determination of the ecosystem, land capability classification and habitats were made Atalay's method (2014, 2018 and Walter 1983). The ecology of Calabrian pine (Atalay et al 1998), Black pine (Atalay and Efe 2010) was used. The growth rate of Pinus nigra and Pinus brutia trees on the parent materials examined (Altunbaş et al., 2019b). Many profiles illustrating the geologic structure, geomorphological properties and the graphs showing parent material and tree growth rate relationship were drawn and the maps of topographic, geologic, soil, land capability classification, ecosystem, ecological unit and geobiomes and so on were prepared. Besides, 12 photos were added to explain all physical and human impact properties of the study area.

Soil texture analysis was conducted by hydrometer method according to the principles determined by Bouyoucos (1955). Organic Substance was classified Walkley-Black method (Black 1965). $\mathrm{pH}$ was measured using a pH meter in a 1: 2.5 soil-water mixture according to Jackson (1967). Electrical Conductivity value was measured using the electrical conductivity instrument in a 1:2.5 soil-water mixture according to Jackson (1967). The $\mathrm{CaCO}_{3}$ content of soil samples was measured by Scheibler Calcimetre. Cation Exchange Capacity was determined according to $1 \mathrm{~N}$ ammonium acetate method (Kacar 1995). Potassium, sodium, calcium and magnesium in the samples were determined in an ICP-OES (Inductively Coupled Plasma) device. 


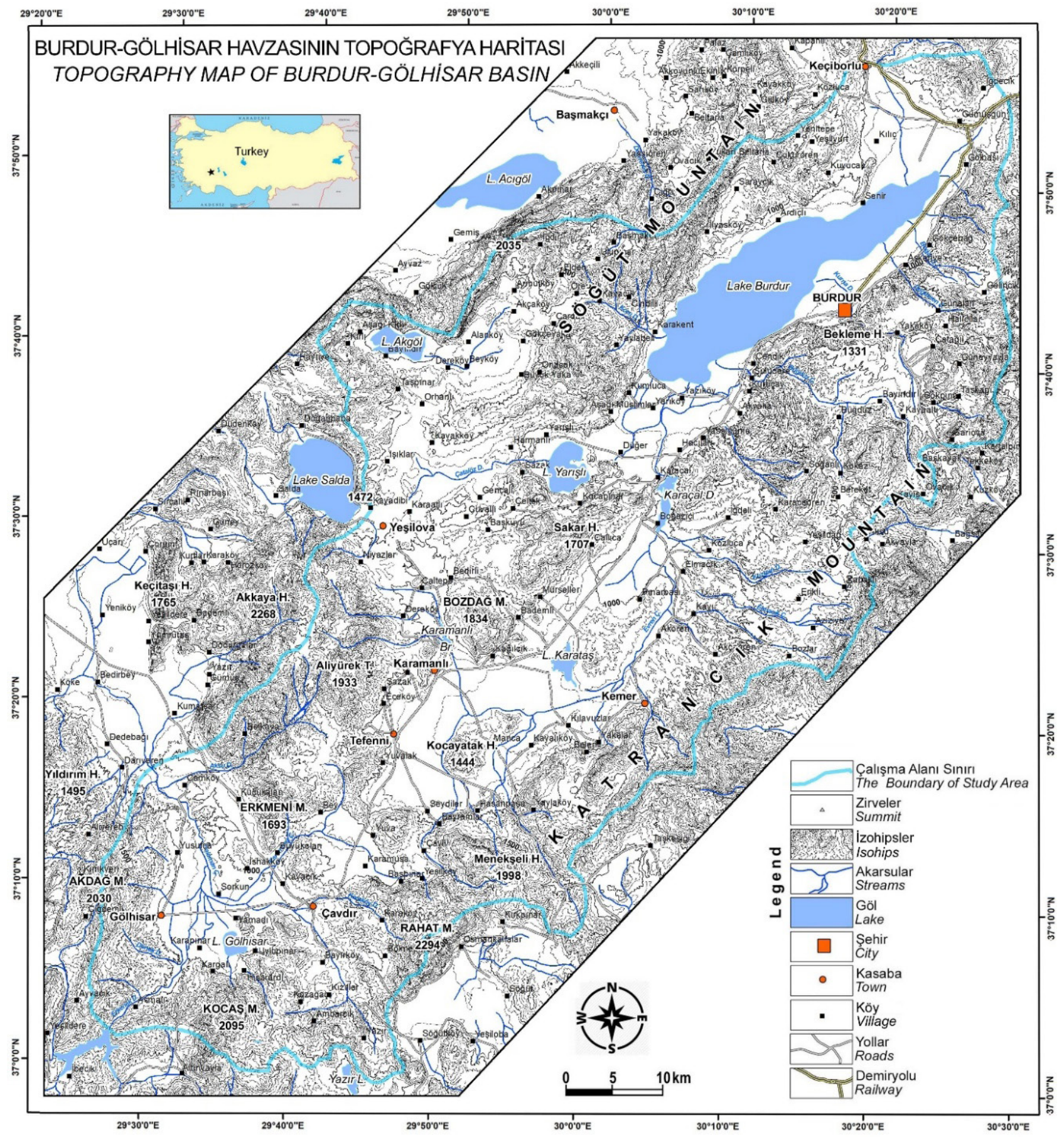

Figure 1: The location and topographic map of Burdur-Gölhisar Basin

\section{FINDINGS}

\subsection{EFFECT OF TOPOGRAPHY ON THE NATURAL ENVIRONMENT}

Burdur-Gölhisar Basin which is located transitional region lying between the Menderes Masse and Taurus mountain belt is one of the active tectonic movements and earthquake areas in Turkey (Atalay et al 2017a, b). The vertical tectonic movements leading to the collapse along the fault lines are mainly responsible for the shaping of present-day topography of Burdur-Gölhisar Basin. On the other hand there are close relationship between topographic-geomorphic units and parent material (Fig 2,3). The established geomorphologic-topographic units forming different natural environments and/or biomes are explained below. 


\subsubsection{Flat Lands-Plains}

These areas covering lowlands extending between Gölhisar and Burdur basins and lowlands of Burdur and Gölhisar depressions are the main occurrence agricultural areas on which agricultural crops mainly cereals are harvested.

Burdur Plain extending as a belt in accordance of the lowlands of Lake Burdur occurs in the northern and southern part of the lake. Presently this plain surface has enlarged depending on the dropping of lake level of Burdur. The southern part of the plain occurring redeposited marl brings about the main dry farming land (Photo 1). But northern continuation of the Lake Burdur Basin is an unproductive area due to salty deposit.

Gölhisar Plain covering the bottom land of the Gölhisar depression is important plain in terms of cash crop vegetable producing areas especially in the green houses. Fruit gardens are found on the irrigation areas in the southern part of the depression (Photo 2).

Akgöl depression lying in the south-western part of Burdur Basin and containing Lake Ak, is in tectonic origin. The lowland which is suitable for agriculture is found on the northern continuation of the depression. The temporary Lake Ak which is formed on the lowest part of the depression changes white colour due to the accumulation of soluble sodium materials with the evaporate of water (Atalay et al., 2017b; Atalay et al.,2019).

The flat land of Tefenni-Karamanlı-Yeşilova: This flat land extending between the basins of Burdur and Gölhisar fits old depression surface with small hills. Dry farming carries out on the chestnut soil (Mollisol) developed on the serpentine. Its relative altitude between the basins of Burdur and Gölhisar is about 150-200 m (Fig. 2, 3, 5).

Flat lands and plains under the semiarid climatic conditions are the main occurrence areas of land capability class IVa. Irrigation areas of plain are found land capability class III (Atalay and Gündüzoğlu 2015; Atalay 2016; Atalay et al., 2019).

\subsubsection{Mountainous Areas}

The edges of Burdur-Gölhisar basins are surrounded by the mountain ranges lying in direction of NE-SW. Soğüt Mountains exceeding $2000 \mathrm{~m}$ of elevation extends as a horst between Burdur and Acıgöl Lake basins. Bozdağ Mountain $(1933 \mathrm{~m})$ which is the highest mountain is found between Yeşilova and Tefenni flat land in the east of Gölhisar depression. The eastern highlands of Burdur and Gölhisar depression is the Katranc1k Mountains which is one of the western ranges of Taurus Mountains. Relative altitude between the lowland and the high mountains is about $1000 \mathrm{~m}$, in general (Fig. 1,2). Mountainous areas which are the main occurrence areas of forest belong to land capability class VII.

The mountain ranges surrounding of the Gölhisar-Burdur basins creates a rainshadow areas. The mean yearly precipitation falling as low as $400 \mathrm{~mm}$ in the Burdur-Gölhisar basins rises up at least $600 \mathrm{~mm}$ on east facing high slopes of the mountains encircling the study area. Because the fronts coming over the Mediterranean Sea are mostly intercepted by the east high slopes of the Katrancik and Söğüt mountains. Thus, rainy areas of the study area correspond to the east facing high slope of the mountains in the study area. In addition to this, orographic rainfall occurring on the upper parts of mountains causes the increase of the precipitation. The increase of the precipitation and the decrease of temperature on the mountains caused the vertical zonation of vegetation. Indeed, the area between c. 1000 and $1300 \mathrm{~m}$ of elevation is the main occurrence area of Calabrian pine (Pinus brutia) forest belt belonging to lower Mediterranean belt of Mediterranean Region. 1300-2000/2200 m is the oro-mediterranean belt which is the main occurrence areas of Pinus nigra subsp. pallasiana (Atalay et. al., 1998; Atalay et. al., 2014; Atalay and Efe 2010; Atalay 2012; 2013; 2014; 2015). The subalpine vegetation is common on the upper part of native timberline of Pinus nigra in the study area. The depressions in the study area are the occurrence areas of temperature inversion during the winter period. For example, the lowest temperature dropped as low as $-20^{\circ} \mathrm{C}$ on the lowest part of depressions, especially in the Burdur depression. The occurrence of the temperature inversion causes severe damages on fruit production. 


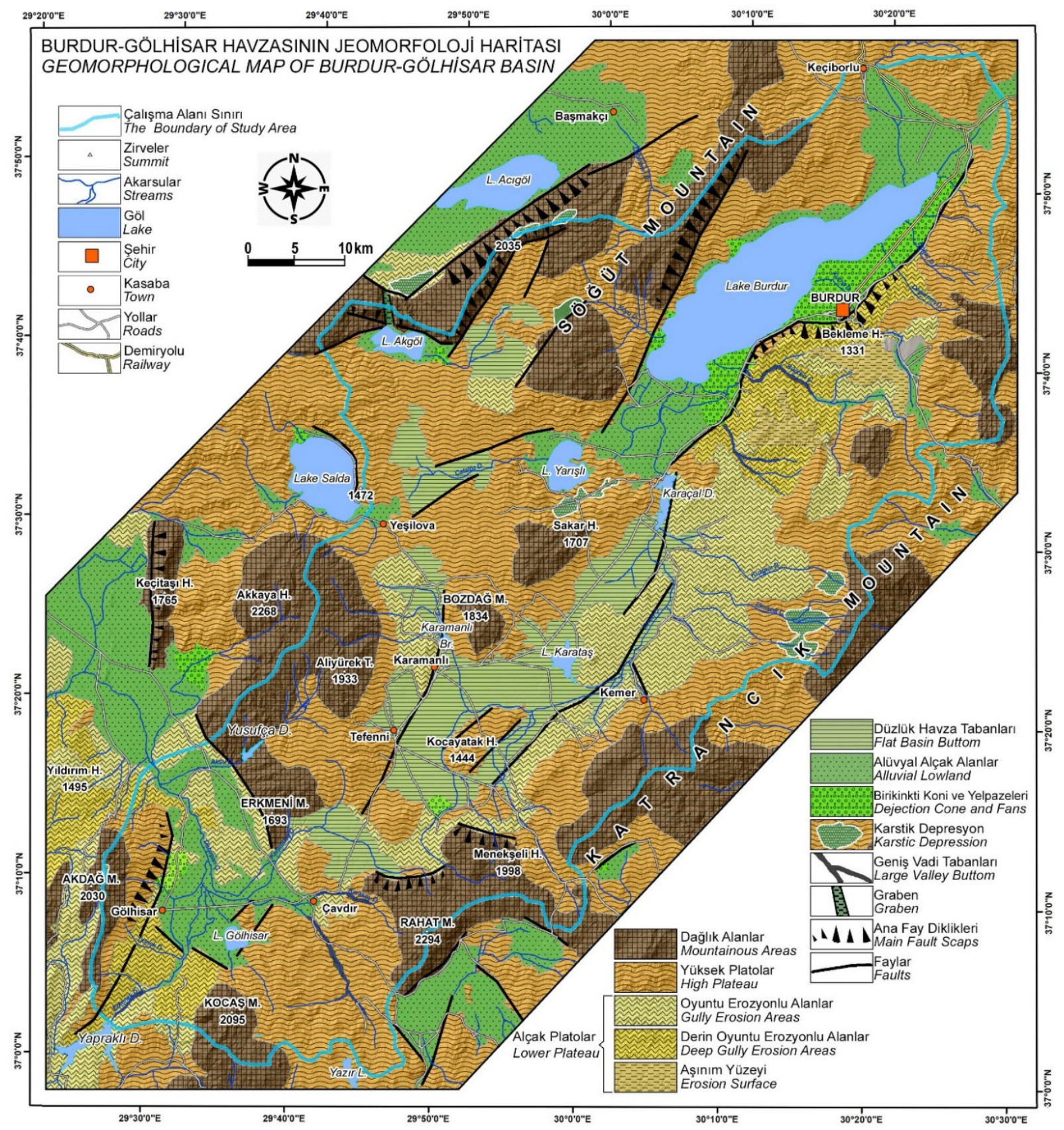

Figure 2. Geomorphic map of Burdur-Gölhisar Basin

\subsubsection{Faulted Topography}

Vertical faulting movements which are responsible for the formation of Faulted Topography in encircling areas of tectonic depressions has led to the severe erosion on the fault scarp and intense sedimentation on the depressed areas. On the other hand, collapsed areas during the mid-Miocene were occupied by the lake in which clay and carbonate-rich sediments were accumulated in the Burdur and Gölhisar basins. The fault scarps have been dissected with triangular spurs valley. Erosion surfaces were formed on the neogene deposits according to the base level of the Burdur and Gölhisar depressions. The erosion surfaces established at elevation of 980, 995, 1040, 1115, 1200 and $1350 \mathrm{~m}$ on the marl deposit in the eastern part of the Burdur depression indicate the rejuvenation of faulting movements to have occurred at least six times (Fig. 3,4). The dissected fault scarps correspond to the intense surface and gully erosion areas especially on the neogene marl deposit (Photo 1, 6,7). While the erosion surfaces on the neogene deposit are one of the dry farming areas belonging to land capability class IVb in the study area (Photo 3,7). 
On the other hand, the erosion surfaces developed different times clearly show the relationship between soil formation and time. The soil thickness is getting increases from the lowest erosion surface to the upper erosion surfaces (Fig. 4). According to study carried away soil formation on the erosion surface indicated that there is no soil cover on the lower erosion surfaces at elevation of 980, 995 and 1040 $\mathrm{m}$, while submature soil profile developed on the 1115 and $1200 \mathrm{~m}$ of elevation and mature soil is found only $1350 \mathrm{~m}$ of elevation (Fig. 3; Atalay et al., 2019, Altunbaş 2018; Altunbaş et al., 2019a).

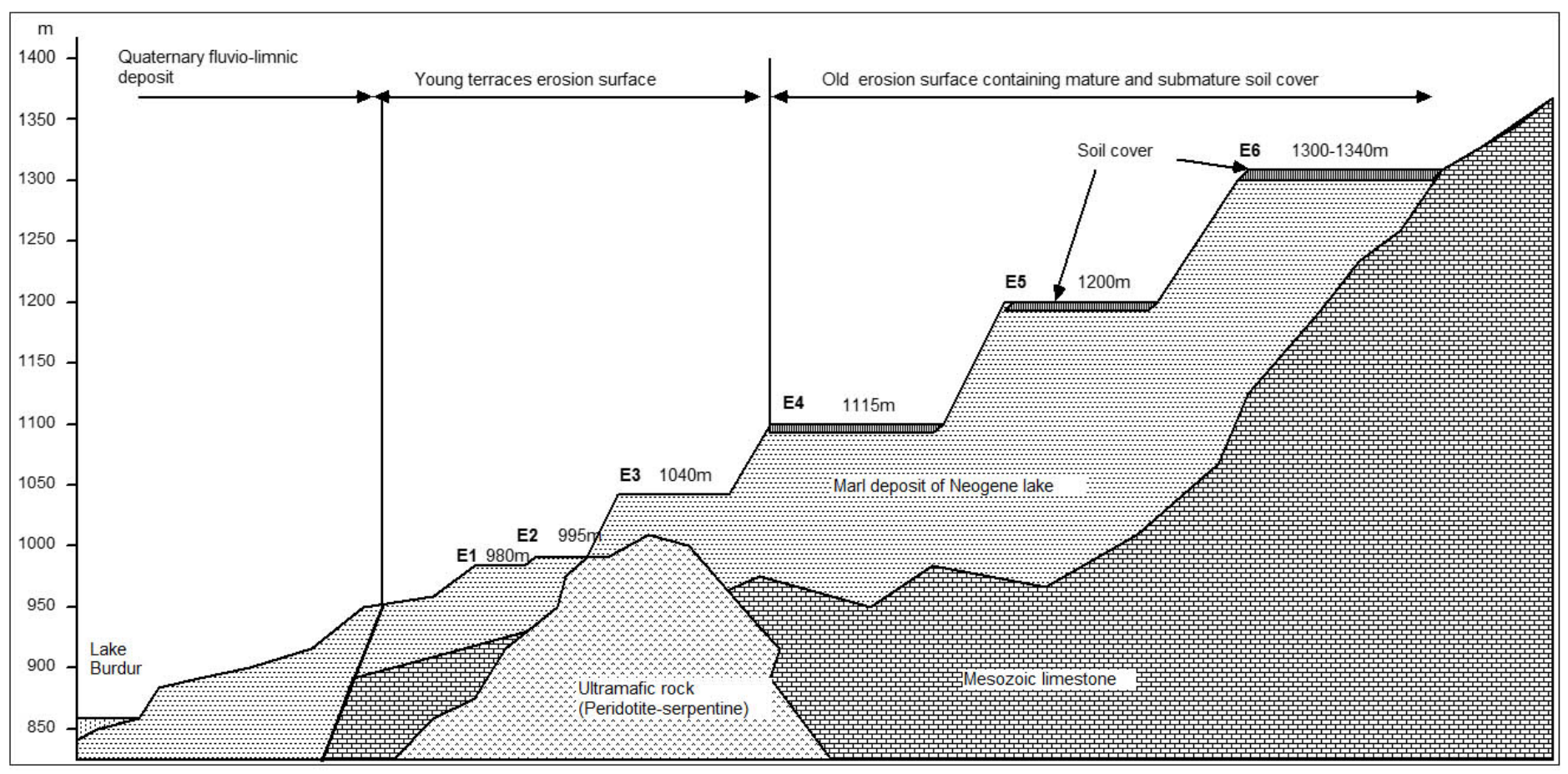

Figure 3: Erosion surfaces formed on neogene marl depending on the base level of Burdur depression. Soil formation has not yet developed on the young erosion surfaces probably belonging to Pliocene-Upper Quaternary.

The lowest part of the depressions was occupied by the lakes which are named Lake Burdur, Lake Karataş, Lake Ak and Lake Gölhisar; they can be regarded as the remnants of the neogene lakes. The Lake Burdur which is nearly $-70 \mathrm{~m}$ at deepest point implies the existence of subsidence occurrence. The soils of hydromorphic and hydromorphic alluvial, and some organic soil on the lowest part of the depressions are the production of the tectonic movements.

\subsubsection{Dejection Fans And Dejection Cone, Colluvial And Lithosol Units}

The dejection fans and cones which are found in the north-eastern and north-western part of Burdur basin have been formed the accumulation of the sandy materials derived from the limestone, conglomerate and sandstone. Dejection cones mainly composed of coarse materials are not suitable for the arable lands due to water infiltration capacity are high. These cones are used for the growth of some fruits like almond, cherry cultivation as seen in the north-eastern part of the Burdur Basin. On the other hand, sandy and partly gravelly soil forming a suitable habitat for the growth of some xerophytic trees mainly Pinus brutia and shrubs like Populus and Quercus coccifera involves land capability class V. The sandy soil area on the flat lands is devoted to rose plantation for production of rose oil and perfumer production (Photo 3, 4, 5; fig. 6). 


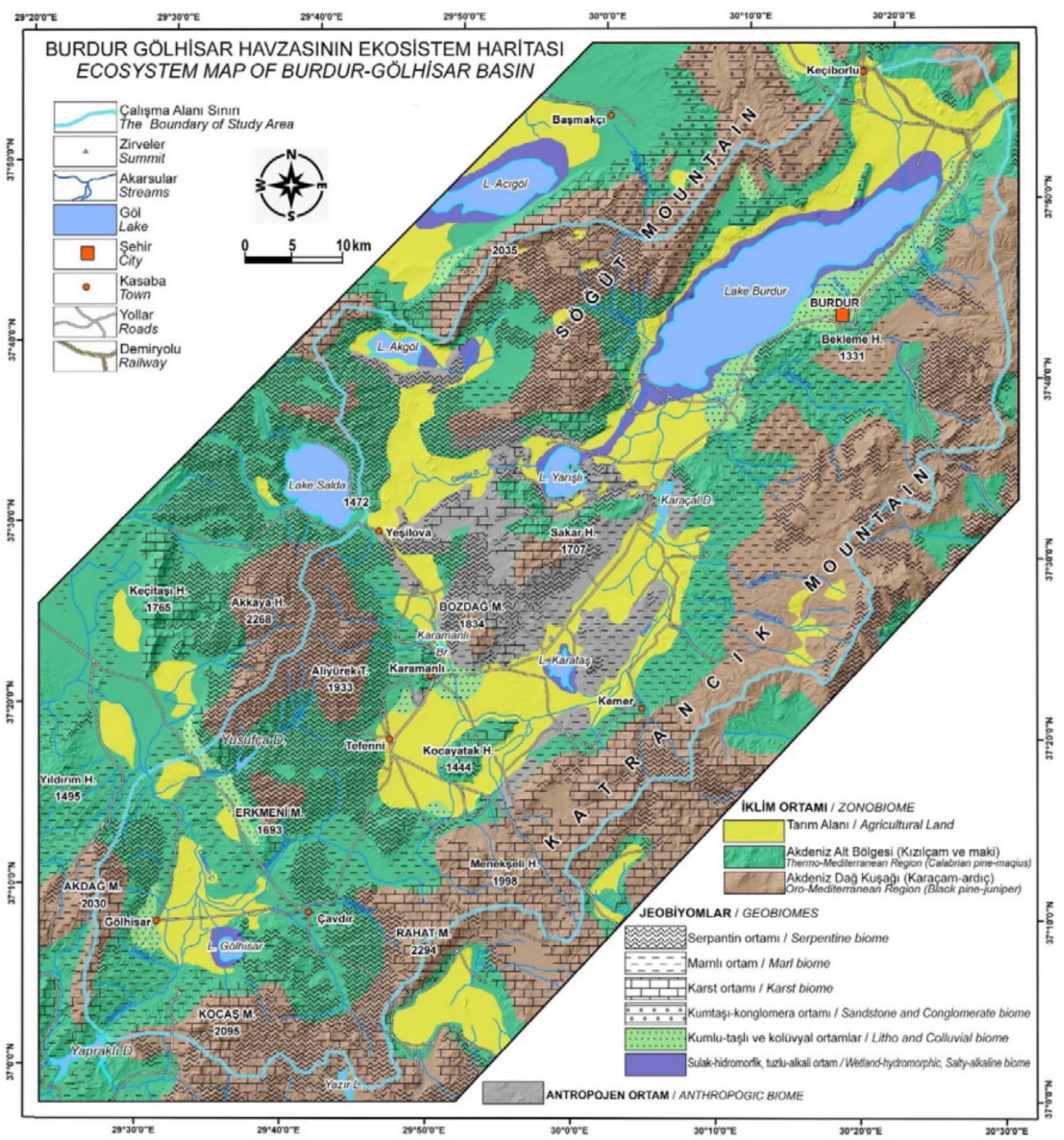

Figure 4: Ecosystem map of Burdur-Gölhisar Basin

Dejection fan developed the accumulation of fine materials like marl and silt is suitable for agricultural activities that are seen on the north-eastern and south-eastern part of Burdur Basin.

Colluvial deposits mainly composed of gravels and sands allowing the development of deep root system are generally covered by the productive forest. The productive forest and maquis vegetation, for example, is found on the colluvial deposit occurring on the lower edges of mountains in the study area. Dejection fans and colluvial deposits which are unsuitable for agriculture belong to land class V.

The gravelly and sandy layers of the fluvio-limnic deposits that are commonly exposed in the west of Gölhisar basin can be regarded as another unit on which productive Quercus coccifera communities are widespread.

Lithosol unit occurs on the forest destroyed sloping areas of serpentine, limestone and conglomerate. Lithosols which can be regarded as skeleton of soils are common on the sloping areas in the eastern and western part of the study area. The lithosols which are suitable for reforestation can be assesses as land capability class VII, but bare and rock lands are found in the class VIII (Fig. 5, 6). 


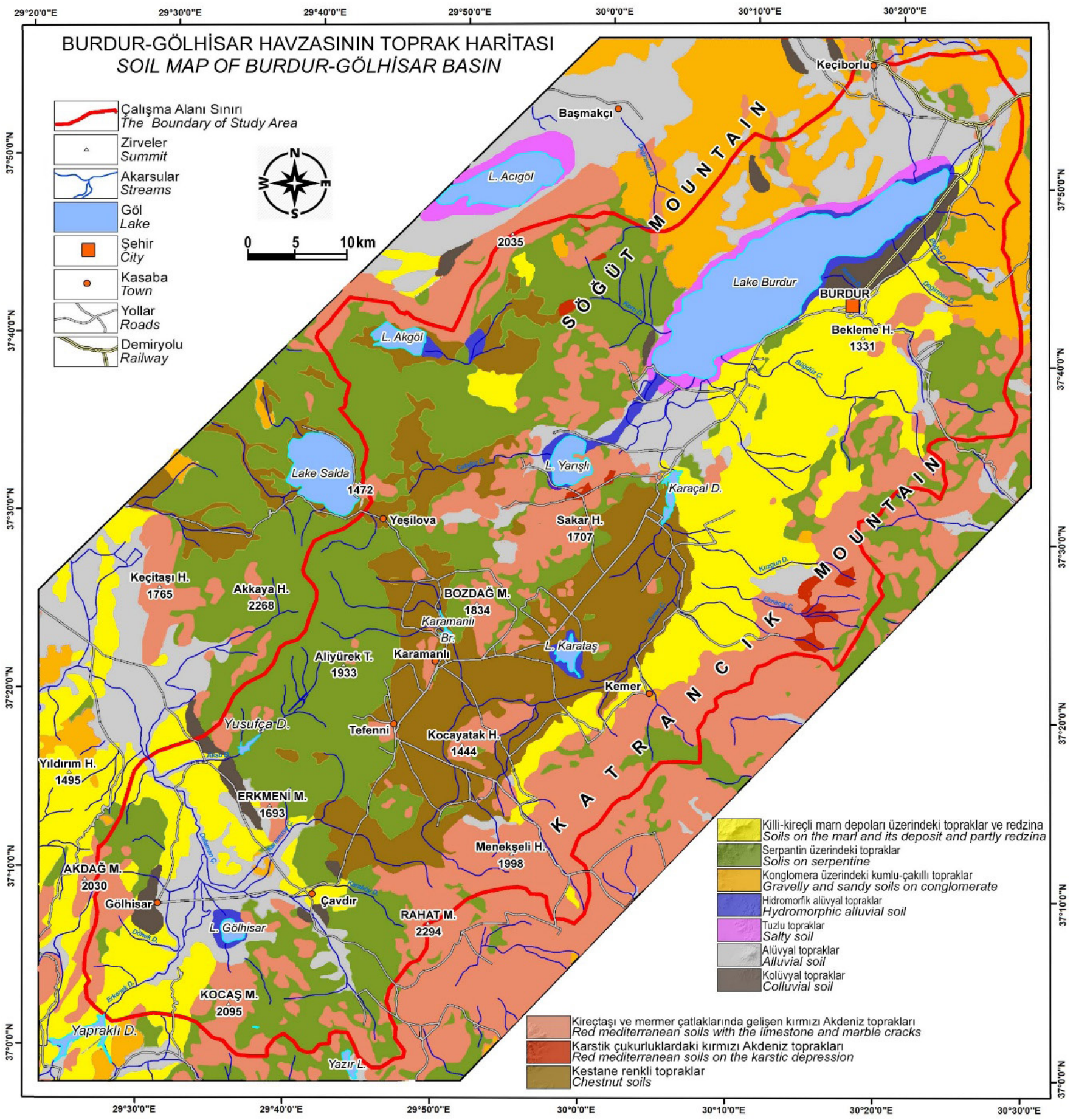

Figure 5: Soil map of the Burdur-Gölhisar Basin 


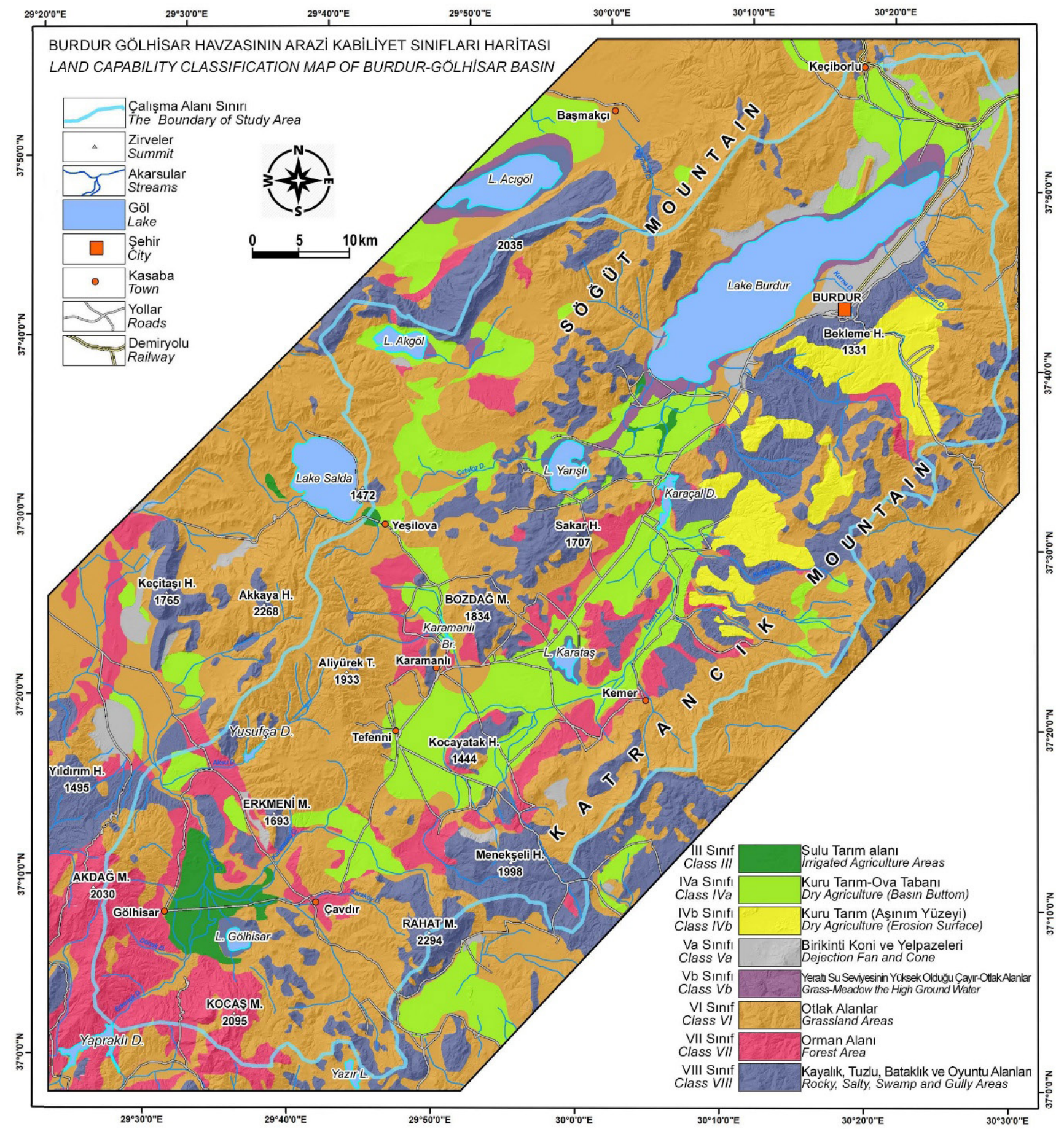

Figure 6: Land Capability class of Burdur-Gölhisar Basin

\subsection{PARENT MATERIAL EFFECTS ON THE NATURAL ENVIRONMENTS}

The physical and chemical traits of exposed parent materials on the sloping areas bring about distinct habitat and/or environment in terms of soil formation, plant productivity, erosion intensity and land capability classification.

The effects of the parent materials on the soil formation and its fertility on the plant growth and land capability classification are explained below. 


\subsubsection{Serpentine-Peridotite}

Peridotite composed of ferro magnesium silicate erupted and spread on the Tethys ocean bottom and serpentine is the hydration product of peridotite. The weathering process of serpentine-peridotite takes very long time due to ferro-magnesium-silicate composition. Serpentine is common on the basement and the highlands of the Burdur-Gölhisar Basin (Fig. 8). The CEC (cation exchange capacity) and/or plant nutriment content changes in a great extent depending on the weathering stages of serpentine. As a general rule, CEC is very low on the unweathered and partly weathered serpentine while it is high on the deeply weathered serpentine. Sparse and low productivity Calabrian pine (Pinus brutia) appears on the unweathered serpentine in the northeastern part of the Gölhisar depression. Here CEC changes between 20-10 $\mathrm{cmol}_{\mathrm{c}} \mathrm{kg}^{-1}$. Bare lands forming VIII land capability class are only seen on the exposed serpentine with CEC is about $220-10 \mathrm{cmol}_{\mathrm{c}}$ $\mathrm{kg}^{-1}$ especially at Taşpınar village locality in the south of Lake Ak. While Good forest stands are found on the deeply weathered serpentine area and colluvial deposit containing weathered serpentine materials in the study area (Table 1,2 and Photo 4).

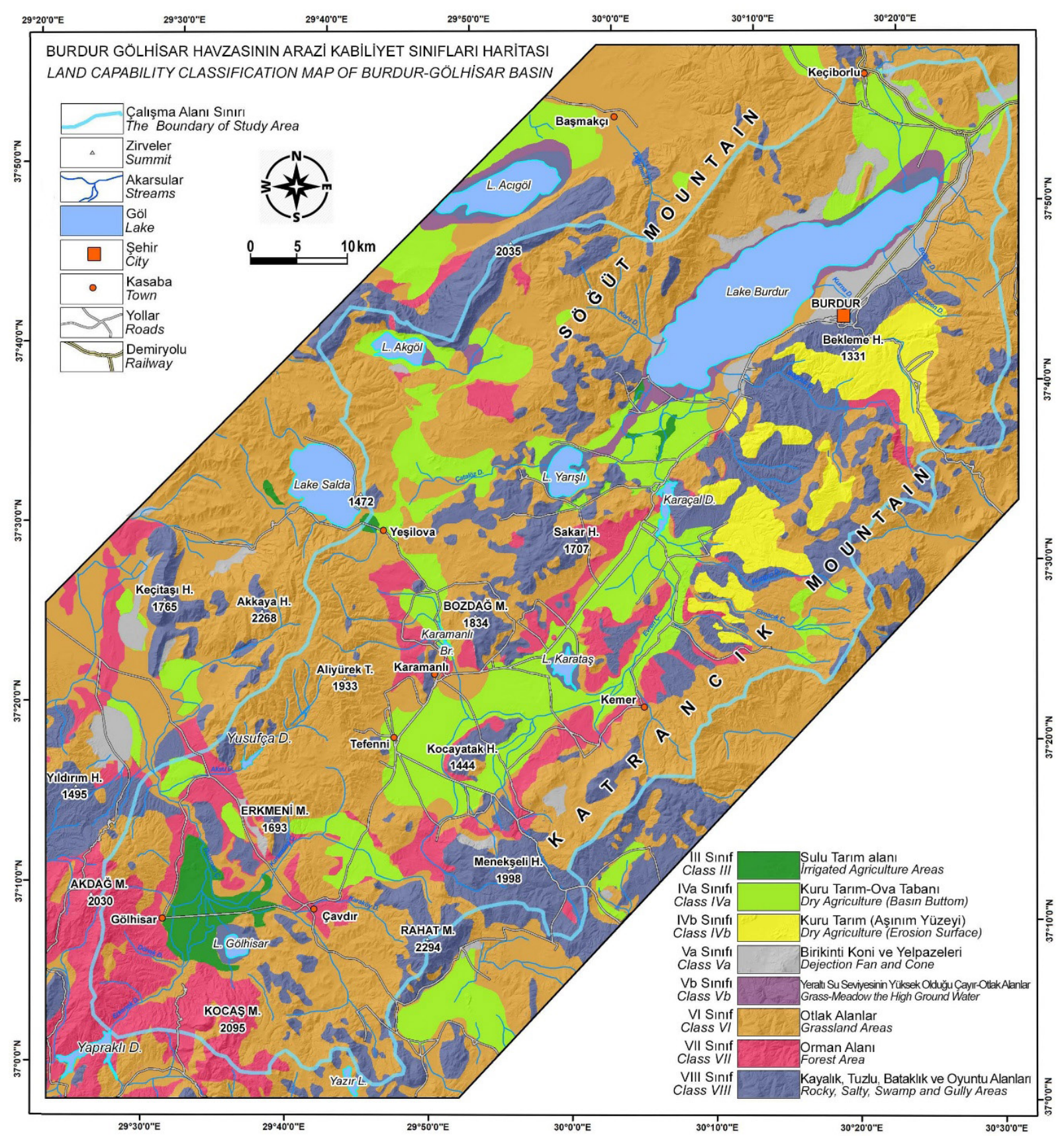

Figure 7: Land capability classification of Burdur-Gölhisar Basin 


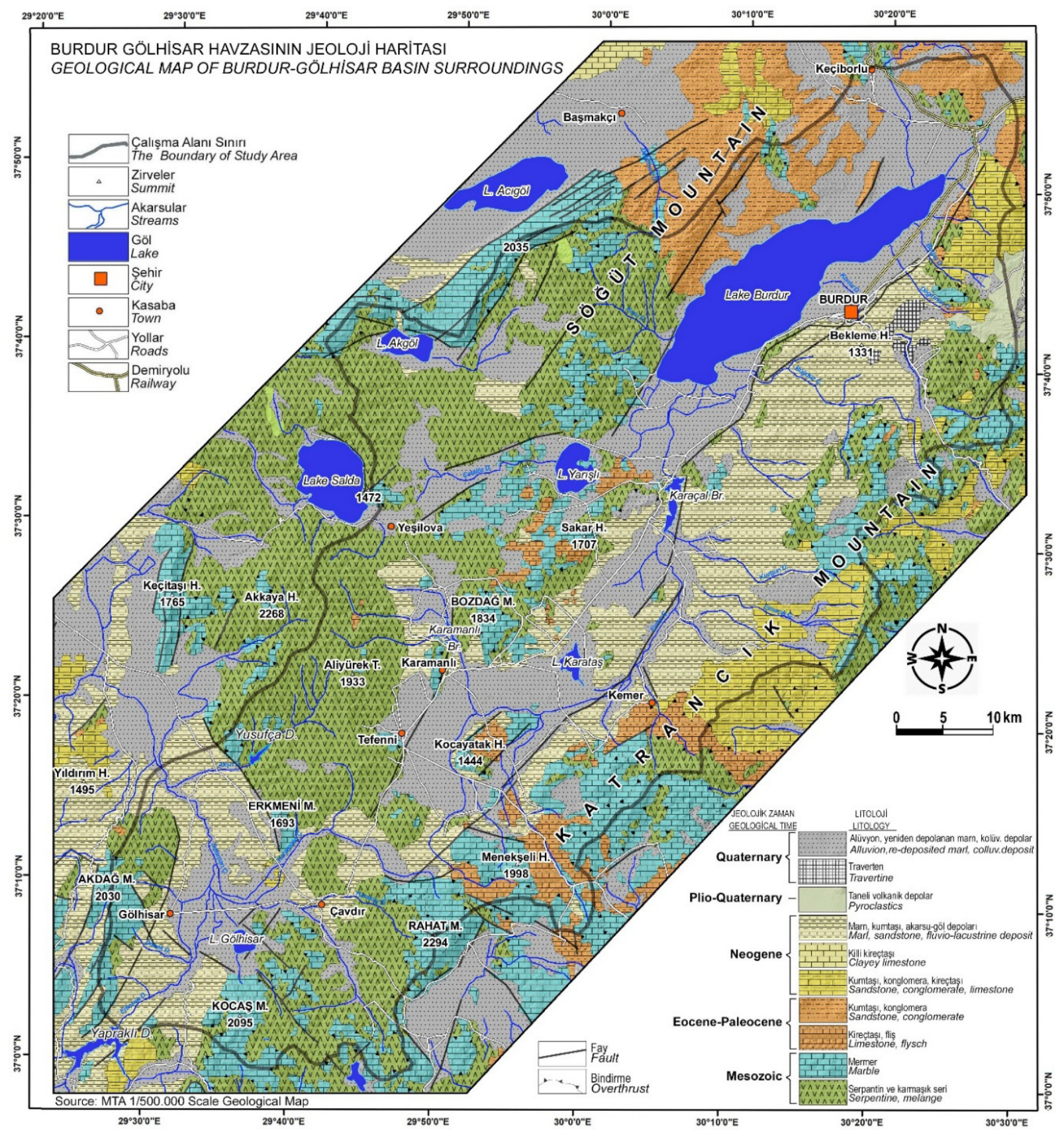

Figure 8: Geologic/parent material map of the Burdur-Gölhisar Basin

On the other hand, soil developed on the serpentine can be considered as fertile soil in local scale on the flat lands occurring between Gölhisar and Burdur Basins. Here CEC is over 40 20-10 $\mathrm{cmol}_{\mathrm{c}} \mathrm{kg}^{-1}($ Table 1, 2). These areas are in class of IV which is suitable for dry farming practise (Fig. 6).

Other property of serpentine is to show profound effects on development of tree roots. The unweathered serpentine mostly prevents the root development, due to the presence of hard surfaces. While serpentines with deep cracked structure form a good habitat for the growth of individual trees, because tree roots easily follow the partly weathered of the cracks and the growth of the roots has led to enlarge of cracks. Besides, the release of the nutriments along the serpentine cracks achieves tend to increase the growth rate of trees. On the other hand, the increase of the released plant nutrients thrive the growth rate of the trees and agricultural fertility. The productive Pinus nigra forests are found on the deeply weathered serpentine, as seen in the west of Gölhisar and southern part of the Söğ̈t Mountains. 
Table 1: Some physical and chemical analysis of different weathered serpentine in the study area

\begin{tabular}{|c|c|c|c|c|c|c|c|c|c|}
\hline $\begin{array}{l}\text { Sample } \\
\text { Location }\end{array}$ & $\begin{array}{l}\text { Weathering stage of } \\
\text { serpentine }\end{array}$ & $\begin{array}{c}\text { Sand } \\
(\%)\end{array}$ & $\begin{array}{l}\text { Clay } \\
\text { (\%) }\end{array}$ & $\begin{array}{l}\text { Silt } \\
(\%)\end{array}$ & Texture & $\mathbf{p H}$ & $\begin{array}{c}\mathrm{CaCO} 3 \\
(\%)\end{array}$ & $\begin{array}{c}\text { Organic } \\
\text { material } \\
(\%)\end{array}$ & $\begin{array}{c}\text { CEC } \\
\text { (cmolc } \\
\text { kg-1) } \\
\end{array}$ \\
\hline SE of Burdur near Çendik beach & Upslope & 91 & 2 & 7 & Sand & 9.5 & 6.5 & 0.3 & 3.16 \\
\hline Akçakale yolu & Serpentine soil & 61 & 20 & 19 & SiL & 9.13 & 1.7 & 0.7 & 23 \\
\hline Kayacık köyü & Flour of serpentine & 65 & 10 & 25 & SiL & 9.12 & 7.11 & 0.5 & 21 \\
\hline Same place & Weathered serpentine & 59 & 21 & 20 & $\mathrm{SiCL}$ & 7.41 & 3.7 & 0.5 & 24.3 \\
\hline Same place & Weathered serpentine & 79 & 7 & 14 & SiL & 7.62 & 5.11 & 0.5 & 33 \\
\hline Same place & Low weathered ser. & 71 & 13 & 16 & SiL & 7.43 & 6.7 & 0.4 & 2 \\
\hline $\begin{array}{l}\text { Taşpınar locality between } \\
\text { Akgöl-Yeşilova town }\end{array}$ & $\begin{array}{l}\text { Weathered serpentine } \\
\text { with rill erosion }\end{array}$ & 67 & 6 & 27 & SiL & 8.55 & 14.9 & 0.1 & 1.8 \\
\hline " & $\begin{array}{l}\text { Only herbaceous } \\
\text { vegetation }\end{array}$ & 65 & 9 & 26 & SiL & 7.28 & 2 & 2 & 14.5 \\
\hline $\begin{array}{l}\text { Upper terrace level } 1200 \mathrm{~m} \\
\text { in the east of Burdur Basin }\end{array}$ & Weathered serpentine & 73 & 9 & 18 & SiL & 7.67 & 9.3 & 0.8 & 66 \\
\hline Same locality & $\begin{array}{l}\text { Good weathered } \\
\text { serpentine }\end{array}$ & 65 & 7 & 28 & SL & 7.67 & 17 & 0.5 & 44 \\
\hline
\end{tabular}

Table 2: Some physical and chemical analysis of serpentine melange area at $2 \mathrm{~km}$ northeast of Yeşilova town, Burdur province

\begin{tabular}{|c|c|c|c|c|c|c|c|c|c|c|}
\hline $\begin{array}{l}\text { Parent material } \\
\text { properties }\end{array}$ & $\begin{array}{c}\text { Sand } \\
(\%)\end{array}$ & $\begin{array}{l}\text { Clay } \\
\text { (\%) }\end{array}$ & $\begin{array}{l}\text { Silt } \\
(\%)\end{array}$ & $\begin{array}{l}\text { Texture } \\
\text { class }\end{array}$ & $\begin{array}{c}\mathrm{CaCO} 3 \\
(\%)\end{array}$ & $\begin{array}{c}\mathrm{K} \\
\text { (cmolc kg-1) }\end{array}$ & $\begin{array}{c}\mathrm{Ca} \\
\text { (cmolc kg-1) }\end{array}$ & $\begin{array}{c}\mathrm{Mg} \\
\text { (cmolc kg-1) }\end{array}$ & $\begin{array}{c}\mathrm{Na} \\
\text { (cmolc kg-1) }\end{array}$ & $\begin{array}{c}\text { CEC } \\
\text { (cmolc kg-1) }\end{array}$ \\
\hline $\begin{array}{l}\text { Deeply weathered } \\
\text { reddish serpentine }\end{array}$ & 46 & 25 & 29 & L & 33 & 0.3 & 36.3 & 13.5 & 0.12 & 34.4 \\
\hline $\begin{array}{l}\text { Deeply weathered } \\
\text { reddish serpentine }\end{array}$ & 37 & 29 & 24 & $\mathrm{CL}$ & 23 & 0.4 & 37.5 & 14.7 & 0.13 & 43.8 \\
\hline $\begin{array}{l}\text { Low weathered } \\
\text { serpentine }\end{array}$ & 79 & 9 & 12 & LS & 33.7 & 0.05 & 20.8 & 2.8 & 0.03 & 13.8 \\
\hline
\end{tabular}

The CEC of the serpentine depends on the amount of the released mainly clay, $\mathrm{Ca}, \mathrm{Mg}$ and other cations in the study area. For example, the $\mathrm{CEC}$ is about $14 \mathrm{cmol}_{\mathrm{c}} \mathrm{kg}^{-1}$ in the serpentine containing $2.8 \mathrm{cmol}_{\mathrm{c}} \mathrm{kg}^{-1} \mathrm{Mg}$, while these figures are 44 and $15 \mathrm{Mg}$, respectively (Table $1,2)$.

\subsubsection{Marl}

Marl composed clay and carbonate was formed with accumulation of calcareous mudstone on bottom of Neogene Lake in the depressions of the Burdur and Gölhisar. The upper section of marl deposit contains fluvial layers and lenses indication regression phases of Neogene Lake. The importance of marl deposits on the soil formation, erosion, plant growth and agricultural activities etc. depends on texture, stratification sequence and the inclination of layers (Photo 5-7; Fig. 8).

Soil formation on the clayey marl deposit takes long time more than at least a few millions in age, in general. Because weathering process of clay-rich sediment is very hard. For this reason, there is no mature soil cover on the neogene marl deposit in the eastern and south-eastern part of Burdur Basin. Besides root development of plants on the clayey marl is in the horizontal direction. This situation prevents the formation of productive forest. While marl deposits containing cracks, sandy and inclined layers supporting the development of taproot system contribute to increase of the plant productivity. Good stand forest, for example, is found on marl deposit with soft and inclined layers in the Burdur-Gölhisar Basin (Photo 5-7 and Fig. 8). 
Table 3: Some physical and chemical analysis of the marl deposit

\begin{tabular}{|c|c|c|c|c|c|c|c|c|c|}
\hline Samples of location and altitude & Lithology of marl & $\begin{array}{l}\text { Sand } \\
(\%)\end{array}$ & $\begin{array}{l}\text { Clay } \\
(\%)\end{array}$ & $\begin{array}{l}\text { Silt } \\
(\%)\end{array}$ & Texture & $\mathbf{p H}$ & $\begin{array}{c}\mathrm{CaCO} 3 \\
(\%)\end{array}$ & $\begin{array}{c}\text { Organic } \\
\text { material } \\
(\%)\end{array}$ & $\begin{array}{c}\text { CEC } \\
\text { (cmolc kg-1) }\end{array}$ \\
\hline Erosion surface $1350 \mathrm{~m}$ & Marl deposit & 17 & 27 & 56 & SiL & 7.5 & 53.71 & 1.57 & 23.3 \\
\hline Same place & Same & 19 & 42 & 39 & C & 7.53 & 54.33 & 1.64 & 23.4 \\
\hline Kuruçay basin, East of Burdur 1300 m & Sandy marl deposit & 65 & 13 & 22 & SL & 7.32 & 17.65 & 2.13 & 15.4 \\
\hline Akyaka village agricultural field, 1300 m & Silty marl deposit & 19 & 19 & 62 & SiL & 7.50 & 42.41 & 1.83 & 21.4 \\
\hline Bottom of Burdur plain $950 \mathrm{~m}$ & Re-deposited marl & 14 & 62 & 24 & C & 7.73 & 21.73 & 1.98 & 26.4 \\
\hline$"$ & $"$ & 14 & 54 & 32 & $\mathrm{C}$ & 7.62 & 22.37 & 1.98 & 19.8 \\
\hline Kemer & Marl & 1 & 69 & 30 & C & 7.66 & 31.6 & 0.6 & 22.1 \\
\hline $\begin{array}{l}\text { Between Kemer-Kozluca, } \\
\text { SE of Burdur basin }\end{array}$ & Hard, white marl & 43 & 9 & 48 & $\mathrm{~L}$ & 7.64 & 56.2 & 0.7 & 11.4 \\
\hline Same location & Wringled marl & 21 & 23 & 56 & SiL & 7.64 & 40.6 & 0.4 & 10.5 \\
\hline
\end{tabular}

Severe erosion continues on the steep slopes of marl deposit due to the infiltration capacity very low. For this reason, deep gullies and "V" shaped valleys are widespread along the fault scarps extending eastern part of Burdur basin. Here, initially rills beginning on the steep slopes have converted into small gullies and then large and wide gullies with the collecting of overland flow (Atalay 2018b).

Partly mature soil formed on the marl deposits is rendzina (Mollisol ordo rendoll subordo, Rendzic leptosol); A horizon or topsoil containing dantritic root system is common due to rich organic content and partly weathered of marl. There is a carbonate and clay accumulation in the subsoil. CEC changes between 15-25 $\mathrm{cmol}_{\mathrm{c} \mathrm{kg}} \mathrm{kin}^{-1}$ accordance with the increase of organic material content and weathering degree (Table 3). Neogene marl deposits on the flat lands especially in the study area are devoted to mostly dry farming areas on which cereals notably barley and wheat are harvested (Photo 1,3).

On the other hand, erosion of marl deposit on the undulating area does not prevent considerably the agricultural production and fertility, because agricultural activities continue on the exposed new and/or fresh marl deposit. Essentially, marl deposit can be assessed as the semiweathered soil.

As to vegetation cover of marl deposit, undulating areas of marl deposit are often covered by Calabrian pine (Pinus brutia), Anatolian black pine (Pinus nigra) in accordance climatic conditions prevailing in the study area. The dominant vegetation on the marly deposit is Quercus coccifera communities because of the fact that this oak species is very resistant drought and over grazing. But continual overgrazing has caused to decrease biomass productivity and sparse distribution of Quercus coccifera communities. On the other hand, that the transporting of the seeds of herbaceous vegetation and pine trees on the steep slopes of gullies have caused the formation of bare land on the marl deposit (Photo 6,7).

\subsubsection{Limestone}

Limestone forming karstic landform creates a special environment as compared with other rocks. The amount of clay content, crack or fissure and the inclination of limestone layers in the karstic land are responsible for the soil formation properties. As a general rule, red Mediterranean soil has developed along the cracks and among the layers on the sloping area (Atalay 1997, 2011, 2016, Sar1 et al 2018, Altunbas 2019b). Rich red Mediterranean soils are found in the limestone containing abundant cracks and very low clay content in the middle part of the Söğüt Mountains in the NW of the Burdur Basin (Photo 8). While clayey limestones and marbles containing very low cracks are mostly prevent the formation of red Mediterranean soil. These areas are widespread in the vicinity of marble quarries in the study area. Other red Mediterranean soil is common on the bottom of karstic depression such as Aziziye polje in the east and middle part of Söğüt Mountains (Photo 9).

Other important property of karstic land is to allow to form a good native regeneration of forest trees and to remain the maquis vegetation as stabilized vegetation (Atalay 2014). Namely, tree seeds falling within the cracks with soil become easily germinate to form natural forest. Besides, even if maquis vegetation completely destroyed and fired, it regenerates with root suckers on the karstic land. 
These areas containing maquis especially kermes oak (Quercus coccifera) communities are found in the eastern part of Burdur Basin, the isolated hilly area between Gölhisar and Burdur basins, fault scarps on the limestone in the north of Lake Akgöl basin, and the western slopes of Katranc1k Mountains in the NE of the study area. On the other hand, the presence of the juniper communities is related to the germination of juniper seeds within the cracks of limestone (Atalay 1995; Atalay 1999; Atalay et al., 2018).

\subsubsection{Conglomerate-Sandstone}

Conglomerate-sandstone with calcareous cement material appears in the NW of Burdur basin (Fig. 8). Here the weathering of the calcareous cement especially along the soft zone and cracks has caused disintegration of conglomerates and sandstones as gravels and sands. In other words, the formation of the soil is related to the chemical dissolution and/or weathering product of calcareous cements of conglomerate and sandstone. For this reason, soil developed on and the soft zone of the conglomerate-sandstone is generally sandy loam in texture (Fig. 9, 10; photo 11). The clay and unweathered sand and gravel particles remain as residual materials in the weathered zone (Atalay et al., 2016).

Soft zones and cracks of conglomerate-sandstone support the taproot development of Calabrian pine (Pinus brutia) and black pine (Pinus nigra) trees and shrubs mainly kermes oak (Quercus coccifera). Indeed, good stand forests and productive maquis vegetation are found on these areas.

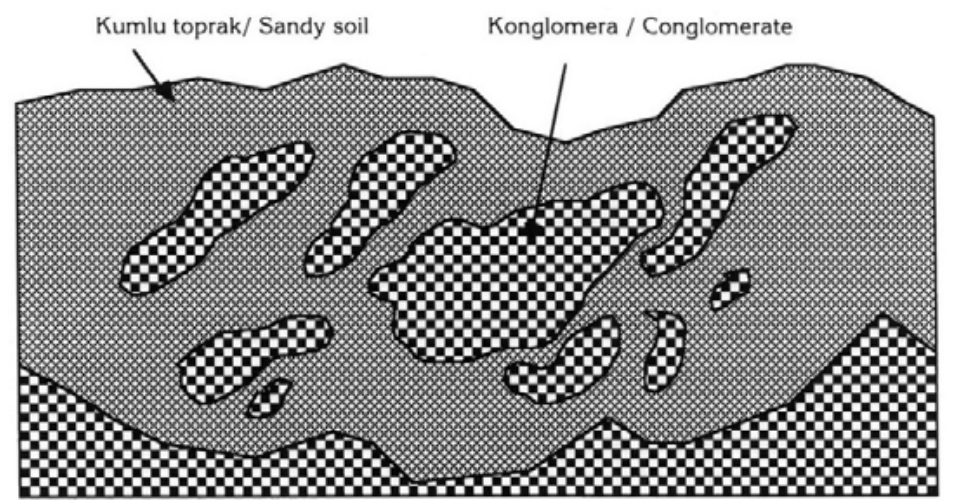

Figure 9: Sandy soil formation with the weathering of calcareous cement in the northwest of Burdur Basin

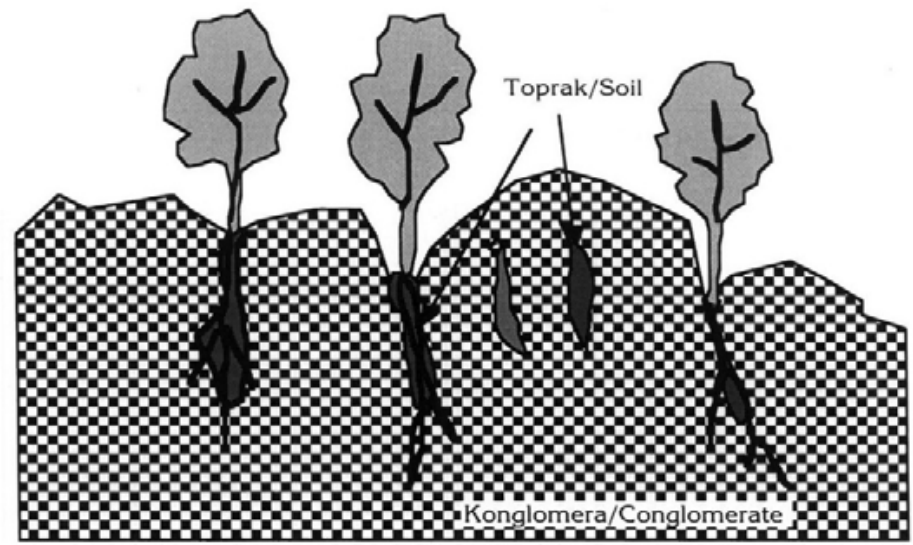

Figure 10: Trees and shrubs growing along the cracks and soft zone of conglomerate in the northern continuation of Sögüt Mountains

Sandy soil produced from the conglomerate-sandstone on the flat and slightly undulating areas in the northern continuation of Söğüt Mountains is devoted to the gardens of rose and levanter.

Conglomerate-sandstone converts to rocky land when the removal of the sandy soil on the sloping area. In such area one can see a very sparse juniper sp and the bitter and spiny herbaceous species to be not eaten by animals (Photo 10). 


\section{CONCLUSIONS AND DISCUSSIONS}

Geomorphologic units are one of the important factors in the determining mainly of vegetation distribution, soil formation and land capability classification units. The physical and chemical properties of parent materials often give some important data on the soil fertility, plant growth and the amount of sediment supplies, sedimentation process and so on in the given area.

The presence of the geomorphic-topographic units and parent materials properties on the Burdur-Gölhisar natural environment and some critic evaluates are as follows:

1. Plains of the study area correspond to the agricultural area in class of III and IV; mountainous areas belonging to land capability class of VII are the suitable for the growth of forest in terms of prevents erosion, obtain forest products and maintain natural equilibrium.

2. Fault scarps corresponding to intense gully erosion areas especially on the marl deposit are the main spreading areas of poor vegetation and bare land.

4. Dejection fans and cones and colluvial deposits which are found in the class V is suitable mostly for the growth of some tree's cultivation.

5. The altitude ranging 900 and $2400 \mathrm{~m}$ brought about three vegetation belt, namely $900-1300 \mathrm{~m}$ is the main occurrence areas of Calabrian forest belt growing under the a somewhat cold winters and dry-hot summers, 1300-2000 m is oro-Mediterranean Pinus nigra forest belt and the area more than more than $2000 \mathrm{~m}$ elevation is the subalpine belt.

6. Growth rate of forest trees is low on compact marl-rich clay deposits but is high on sandy and inclined layers of marl. Erosion surfaces developed on marl and re-deposited marl deposits are one of the main agricultural fields belonging to land capability class IV.

7. Good stand forests and fertile agricultural fields are common on deeply weathered serpentine, while poor forest stands are widespread on unweathered and low weathered serpentine.

8. Limestone and conglomerate-sandstone formed a good environment for the growth of productive forests due to the deeply root development along the crack and soft zone.

9. The land capability classification made in 1974 by Topraksu administration contains many scientific mistakes in the classification of land capability classification and soil types. For example, exposed marl deposit indicated as the spreading areas of brown soil and land capability class of I is showed on the northern part of the Lake Burdur.

10. The of cedar (Cedrus libani) plantation for the reforestation area especially on marl and serpentine is an inappropriate application in terms of ecology in the study area, because cedar grows in the oro-mediterranean forest belt in the Mediterranean Region and outcropped hard serpentine generally prevents the deeply development of cedar roots (Atalay 2015).

\section{Acknowledgement}

This article is produced the research project entitled "Ecology, Ecosystem and Rehabilitation of marble Quarries" supported by Regional Directorate of Isparta Forest, General Directorate of Forestry, Agriculture and Forest Ministry. We would like to thank Kenan Karaduman, Isparta Regional Forest Director, Celal Korkmaz Forest Operational Director of Burdur and Bekir Karacabey General Director of General Directorate of Forestry. 


\section{REFERENCES}

Altunbaş, S., (2018). Pedogeomorphology of the Burdur-Gölhisar Basin, SW Anatolia, Turkey. Fresenius

Altunbaş, S., Atalay, İ., Siler, M. (2019). Relationship Between Geologic Parent Material and Growth Of Forest Trees In The Gölhisar Basin In Sw Anatolia, Turkey. Applied Ecology And Environmental Research 17(5):11085-11106.

Altunbaş, S., Atalay, İ., Siler, M. (2019)b. Soil Formation on the Erosion Surfaces of the Eastern Part of Burdur Basin in SW Anatolia, Turkey, in press.

Atalay, İ. (1977). Burdur havzası ve çevresinin jeomorfolojik gelişimi (Geomorphological evolution of the Burdur basin and its surroundings). Jeomorfoloji Derg., 6:93-110.

Atalay, İ. (1997). Red Mediterranean soils in some karstic regions of Taurus Mountains, Turkey, Catena, 28: 247-260.

Atalay, İ. (1995). Pedogenesis and ecology of karstic lands in Turkey. Acta Carsologica, 24:53-67

Atalay, İ. (1999). Land Use in the Karstic Lands in the Mediterranean Region. International Journal of Speleology. 28 B 1/4. 111:118.

Atalay, İ. (2008), Ekosistem Ekolojisi ve Coğrafyası (Ecosystem Ecology and Geography in Turkish). Meta Basım, İzmir.

Atalay, İ. ve Efe, R.. (2010). Anadolu Karaçamı (Pinus nigra subsp. pallasiana (Lamb.) Holmboe)'nin Ekolojisi ve Tohum Nakli Açısından Bölgere Ayrılması. Ecolog of the Anatolian Black Pine (Pinus nigra subsp. pallasiana (Lamb.) Holmboe) and Its Dividing Into Regions in terms of Seed Transfer. Çevre ve Orman Bakanlığı Yay. No. 424, Tohum Islah Araştırma Müd Yay. No. 37.

Atalay, İ. (2011). Türkiye'de Karstlaşma ve Karst Ekolojisi. Fiziki Coğrafya Araştırmaları Sistematik ve Bölgesel. Türk Coğrafya Kurumu Yay. Sayı 6, s.202-222. İstanbul.

Atalay, İ. (2012). Uygulamalı Klimatoloji (Applied climatology in Turkish, $2^{\text {nd }}$ press). Meta Basım, İzmir.

Atalay, İ. (2013). Tektonik hareketlerin Türkiye Doğal Ortamı üzerindeki etkileri. Effects of the tectonic movements on the Natural Environment of Turkey. Prof. Dr. İlhan Kayan'a Armağan, Ege Üniv. Yay., s. 341-354.

Atalay, İ. (2014). Türkiye'nin Ekolojik Bölgeleri-Ecoregions of Turkey. Meta Basım, İzmir.

Atalay, İ., Efe, R, Öztürk, M. (2014). Effects of Topography and Climate on the Ecology of Taurus Mountains in the Mediterranean Region of Turkey. Elsevier, Procedia - Social and Behavioral Sciences. Volume 120, pp. 142-156

Atalay, İ. (2015). Türkiye vejetasyon coğrafyası (Vegetation Geography of Turkey in Turkish). Meta Basım, İzmir.

Atalay, İ. ve Gündüzoğlu, H. A. (2015). Türkiye'nin Ekolojik Özelliklerine Göre Arazi Kabiliyet Sınıflandırılması. Meta Basım, İzmir.

Atalay, İ. (2016)a. A New Approach to the Land Capability Classification: Case Study of Turkey. Procedia Environmental Sciences. 32:264-274.

Atalay, İ. (2016)b. Toprak Oluşumu, Sınıflandırılması ve Coğrafyası-Soil formation, classification and Geography (5th edition). Meta Basım, İzmir.

Atalay, İ., Efe, R. Soykan, A. and Cürebal, İ. (2017)a. Conglomerate Habitat in the Köprü River Basin in the Western Mediterranean Region of Turkey in Contemporary Studies in Environment and Tourism (Eds: Recep Efe and Münir Öztürk), Chapter28, pp. 453-464, Cambridge Scholar Publishing, Newcastle.

Atalay, İ., Adıgüzel, H. and Dal, N., (2017)b. Geomorphological evolution of the Gölhisar Depression, SW Anatolia, Turkey. International Symposium on Geomorphology, 12-14 October 2017, Proceeding Book Eds: S. Tonbul. T. Şengün, M. Siler, A. Canpolat. pp. 137-145

Atalay, İ., Adıüzel, H, Dal, N. (2017)c. The effects of neotectonic movements on the geomorphic units between Lake Ac1 and Lake Akgöl, SW Anatolia, Turkey. International Symposium on Geomorphology, 12-14 October 2017, Proceeding Book Eds: S. Tonbul. T. Şengün, M.Siler, A. Canpolat. pp. 644-648

Atalay, İ. (2017)d. Türkiye Jeomorfolojisi (Geomorphology of Turkey, in Turkish). Meta Basım, İzmir

Atalay, İ., Saydam, C., Kadir, S., Eren, M. (2018). Pedogeomorphology. in Soils of Turkey. Eds: Kapur, Akça and Günal. pp. 75-104. Springer.

Atalay, İ. (2018)b. Pedogeomorphology. in Soils of Turkey. Springer:75-104.

Atalay, İ., Altunbaş, S., Khan, A. and Coşkun, M. (2018)c. The effects of neotectonic movements of the shaping of topography, karstification and soil formation in the SW part of Taurus Mountain in Turkey. International Geog. Symposium on the $30^{\text {th }}$ Anniversary of TUCAUM. Eds: Türkoğlu, Bayer, Karabacak, Anl1, Kiler and Gökkaya. pp. 608-622.

Atalay, İ, Altunbaş, S., Siler, M. and Dal, N. (2019). Burdur-Gölhisar Havzasının Ekolojisi, Ekosistemleri, Habitatları ve Mermer Ocaklarının Rehabilitasyonu/Ecology, Ecosystem, Habitats And Rehabilitation Of Marble Quarries In Burdur-Gölhisar Basin, NW Anatolia. Tarım ve Orman Bakanlığı, Orman Genel Müdürlüğü Isparta Orman Bölge Müdürlüğü Araştırma Projesi/ Research Project of Isparta Forest Directory, General Directory of Forest, Agriculture and Forest Ministry.

Bailey, R. G. (1995)a. Description of the Ecoregions of the United States. United States Department of Agriculture Forest Service, Pub Nu. 1391, Washington D.C.

Bailey, R. G. (1995)b. Ecosystem Geography. Springer, New York Berlin Hong Kong London Paris Tokyo

Bailey, R. G. (1998). Ecoregions. The Ecosystem Geography of the Oceans and Continents. Springer, New York Berlin, Hong Kong London Paris Tokyo

Black, C. A. (1965). Methods of soil analysis Part 2, Amer. Society of Agronomy Inc., Publisher Madisson, Wilconsin, U.S.A., 1372-1376. 
Bouyoucos GJ (1955): A Reclamation of the Hydrometer Method for Making Mechanical analysis of the soils. Agronomy Journal 4(9): 434.

Cohen, R. and Erol, O. (1969). Aspects of the Paleogeography of south Central Anatolia: Geog Journal, 135:338-398.

Erol, O. (1975). Burdur havzası Kuvaterner depolar1- Quaternary deposits of Lake Burdur: Cumh. 50. Y11 Yerbilimleri Kong., MTA, Enst. Yay.: s. 386-390.

Jackson, M. C. (1967). Soil chemical analysis. Prentice Hall of India Private Limited, New Delhi.

Kacar, B. (1995). Bitki ve toprağın kimyasal analizler: III. Toprak Analizleri. A. Ü. Ziraat Fakültesi Geliştirme Vakfı Yayınları No: 3.

Orman ve Su İşleri Bakanlığı Çölleşme ve Erozyonla Mücadele Genel Müdürlüğü. (2014). Burdur ve Çevresi Ağaçlandırma ve Erozyon Kontrolü çalışmalarının değerlendirilmesi Çalışma Raporu, Ankara.

Sarı, M., Kurucu, Y., Akça, E., Eren, M., Kadir, S., Günal, H., Zucca, K., Atalay, İ., Kaya, Z., Previtali, F., Zdruli, P., Kapur, S. and FitzPatrick. (2018). Luvisol. in Soils of Turkey. Eds.: S. Kapur, E. Akça, H. Günal. pp. 231-250. Springer.

Sungur, K. (1974). Burdur, Acıgöl depresyonları ve Tefenni ovasının fiziki coğrafyası: İ.Ü. Coğ. Enst. Yay.: 95, İstanbul.

Tetik, M., Yeşilkaya, Y. (1997). Antalya Yöresi doğal kızılçam ormanlarında anakaya-toprak derinliği-bonitet ilişkileri teknik Böl no 6, Batı Akdeniz ormancılık araştırma Müd. Yay.

Topraksu. (1974). Burdur-Göller havzası toprakları. Topraksu Genel Müd. Yay. No. 304.

Walter, H. (1983). Vegetation of the Earth and Ecological system of Geo-biosphere. Springer-Verlag, Berlin, New York, Toronto 


\section{PHOTOS}

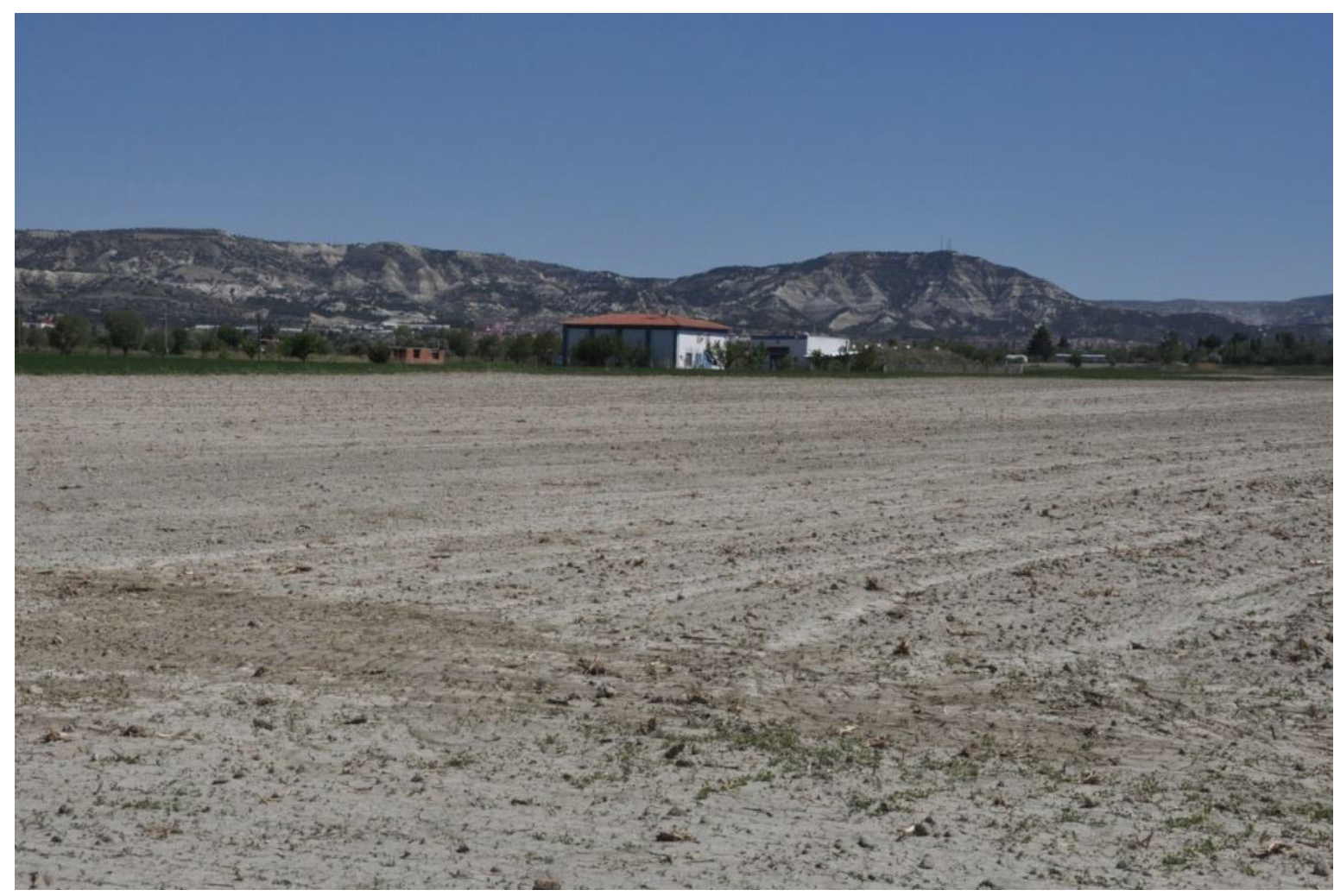

Photo 1: Fault scarp cutting neogene marl deposit in background and re-deposited marl on the southern part of Burdur Basin

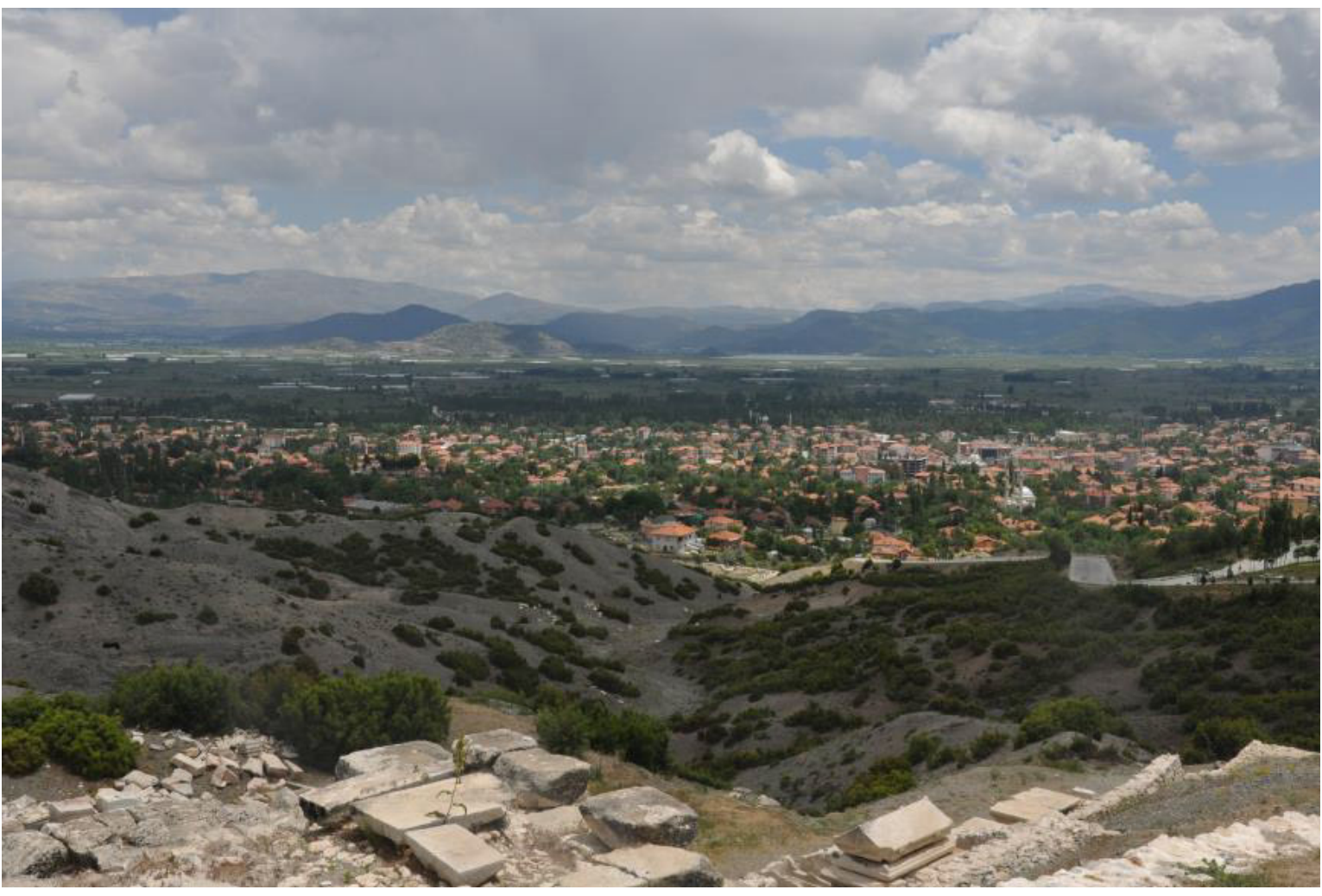

Photo 2:A view from the south to Gölhisar town and tectonic depression 


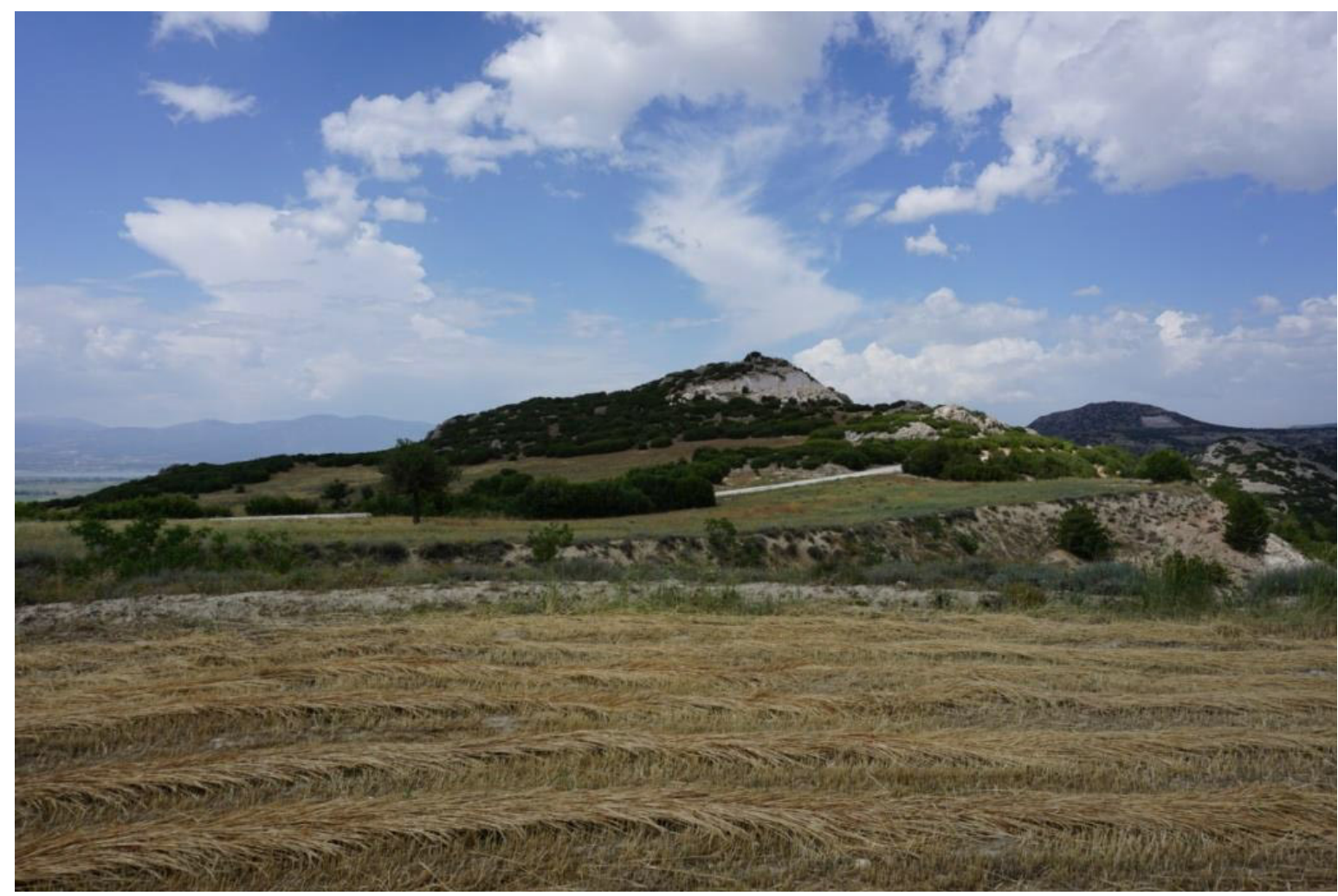

Photo 3: Agricultural land belonging to class IVb and harvesting barley and wheat on the upper erosion surface c. $1200 \mathrm{~m}$ elevation on marl deposit in the eastern part of Burdur Basin

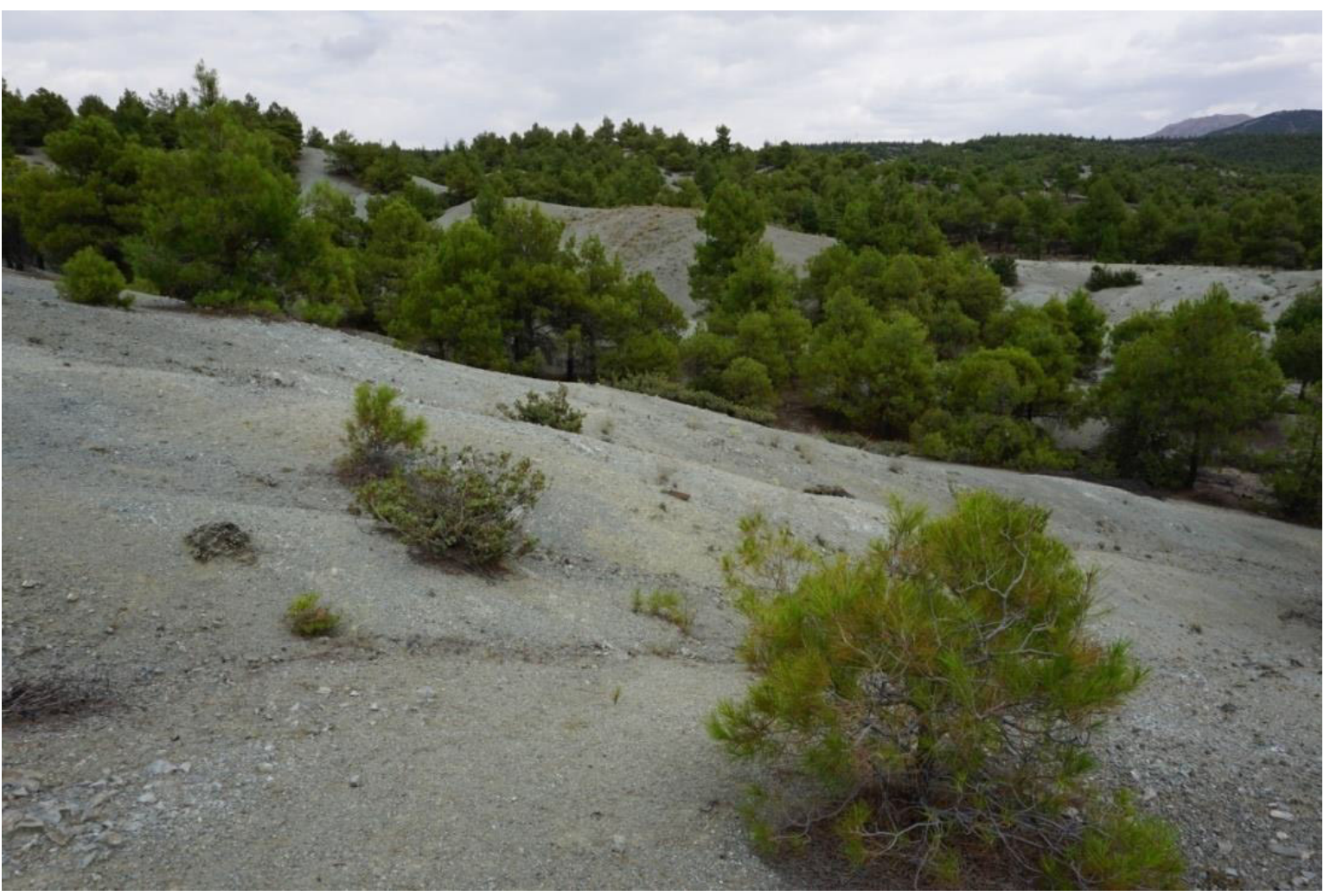

Photo 4: Exposed serpentine and Calabrian pine in the different growth rate according to weathering stage at the connection of Gölhisar-Çavdır highway in the west of Gölhisar Basin. 


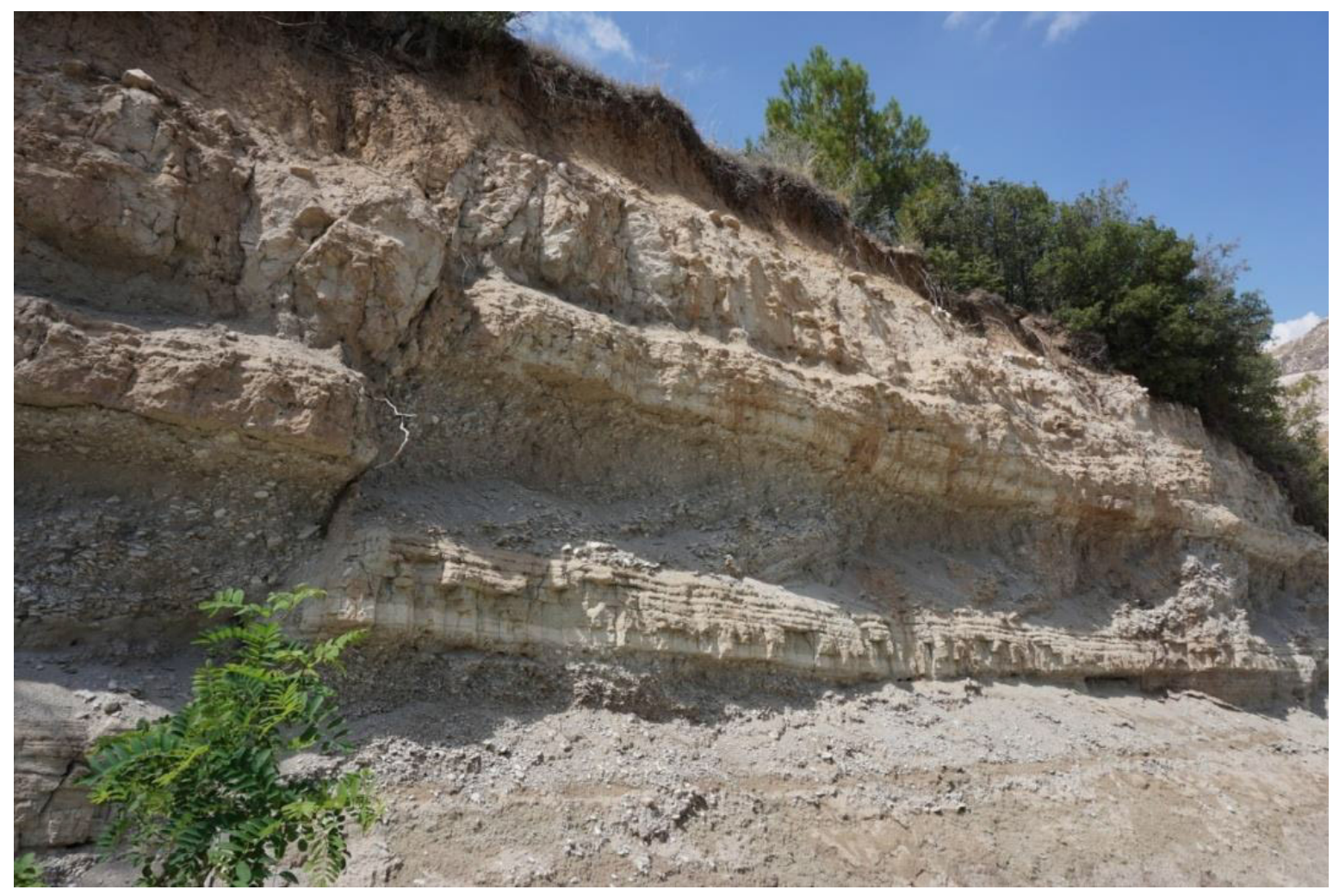

Photo 5: Layers of marl deposit containing fluvial sand and gravels indication regression phases in the lake environment in the east of Burdur Basin

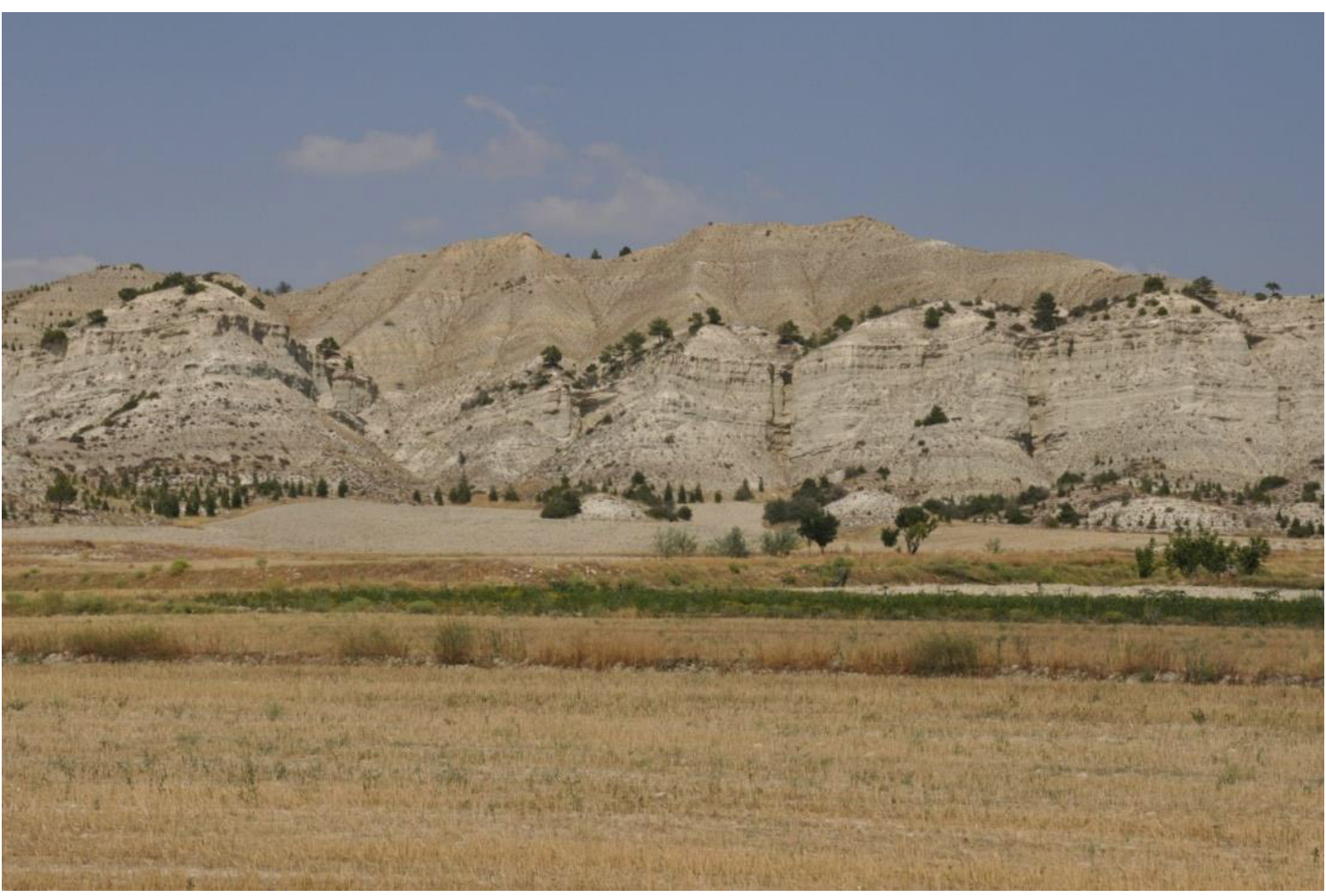

Photo 6: Fault scarp dissected the marl deposit by gullies in the northern edge of Kemer Basin 


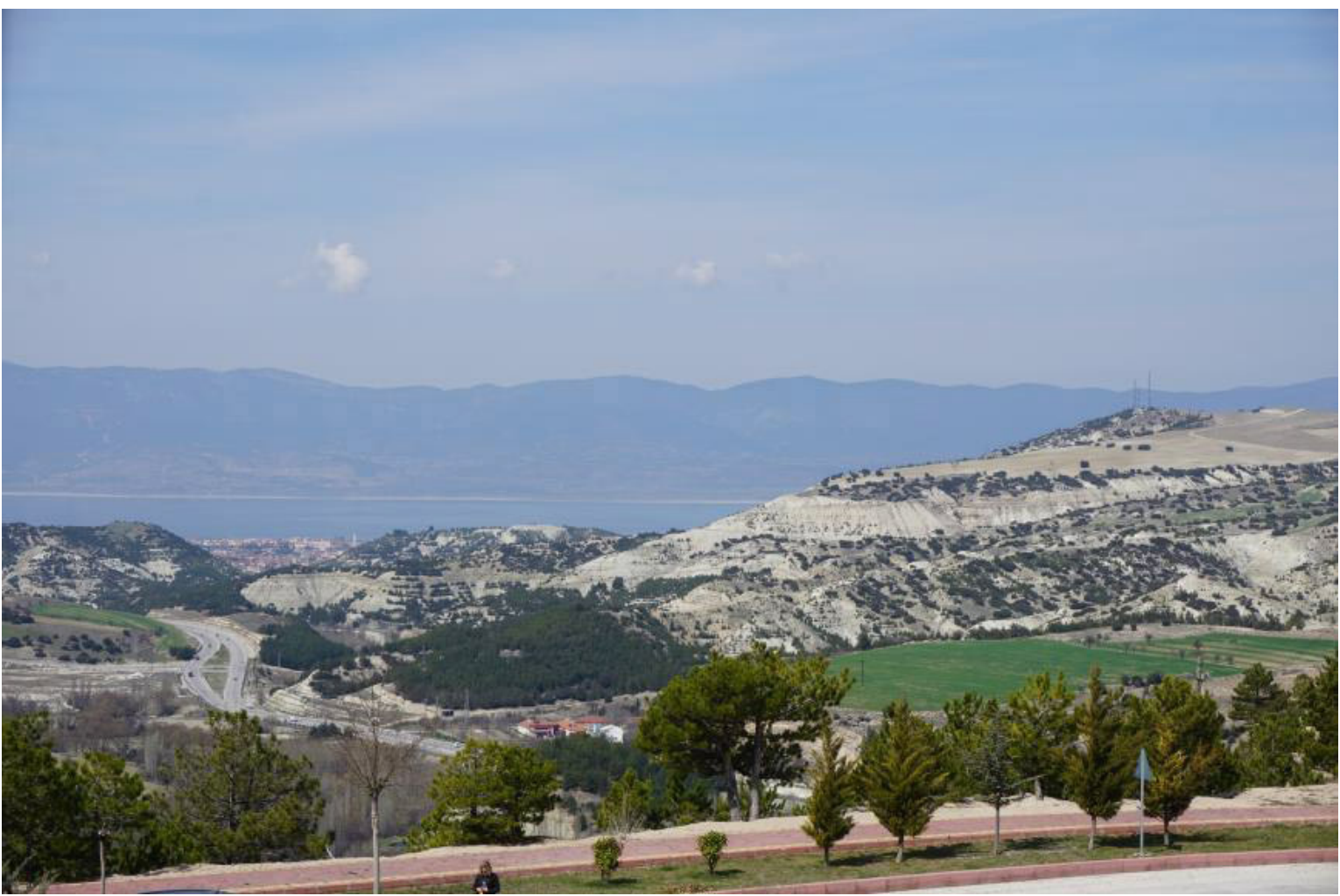

Photo 7: A view from M. Akif University Campus to Lake Burdur. Agricultural areas (green) on the erosion surface of marl, other erosion surface $(1,2)$ and dissected faulted topography

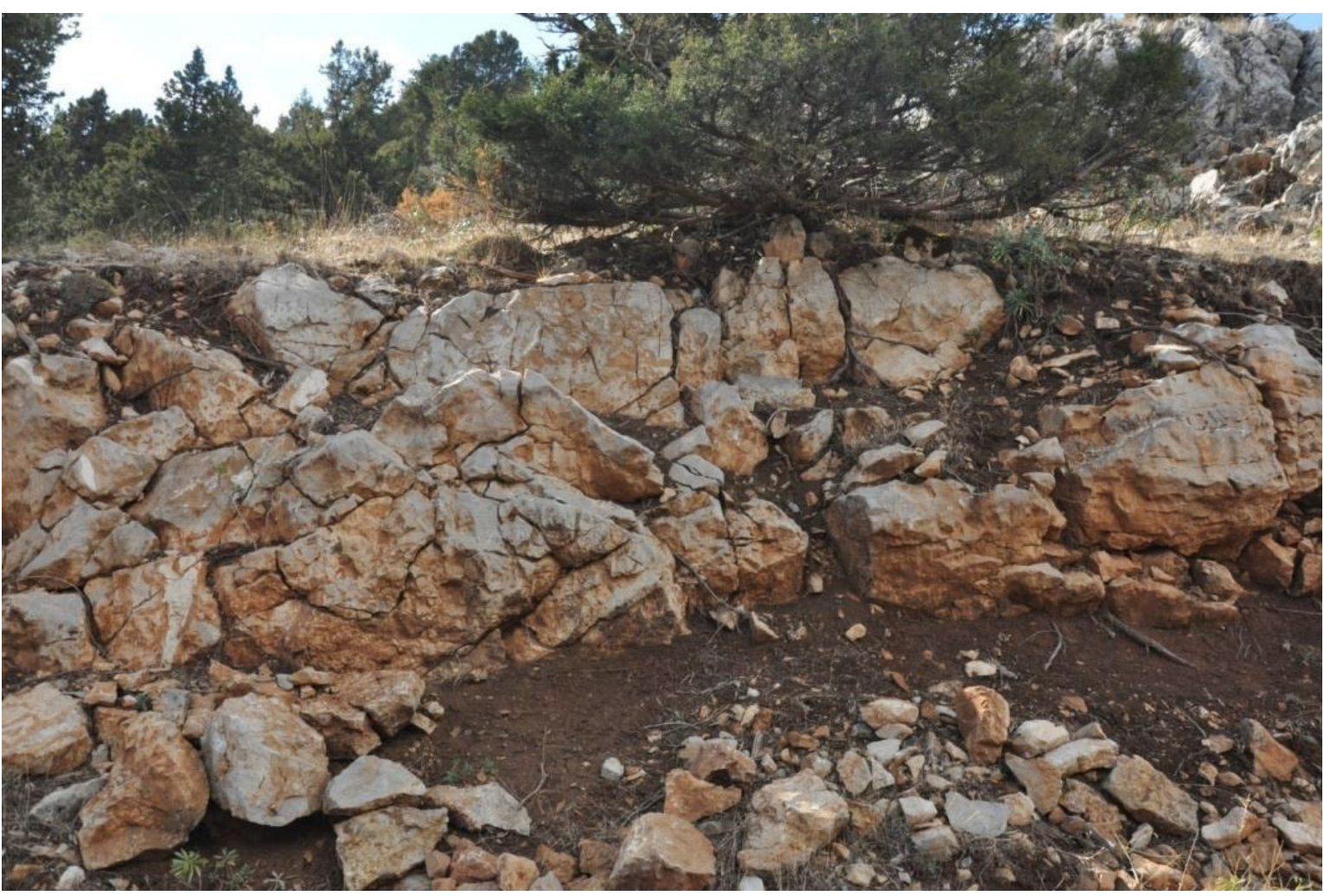

Photo 8: Red Mediterranean soil developed along the cracks of Mesozoic limestone in the Söğ̈̈t Mountains, NW of the study area. 


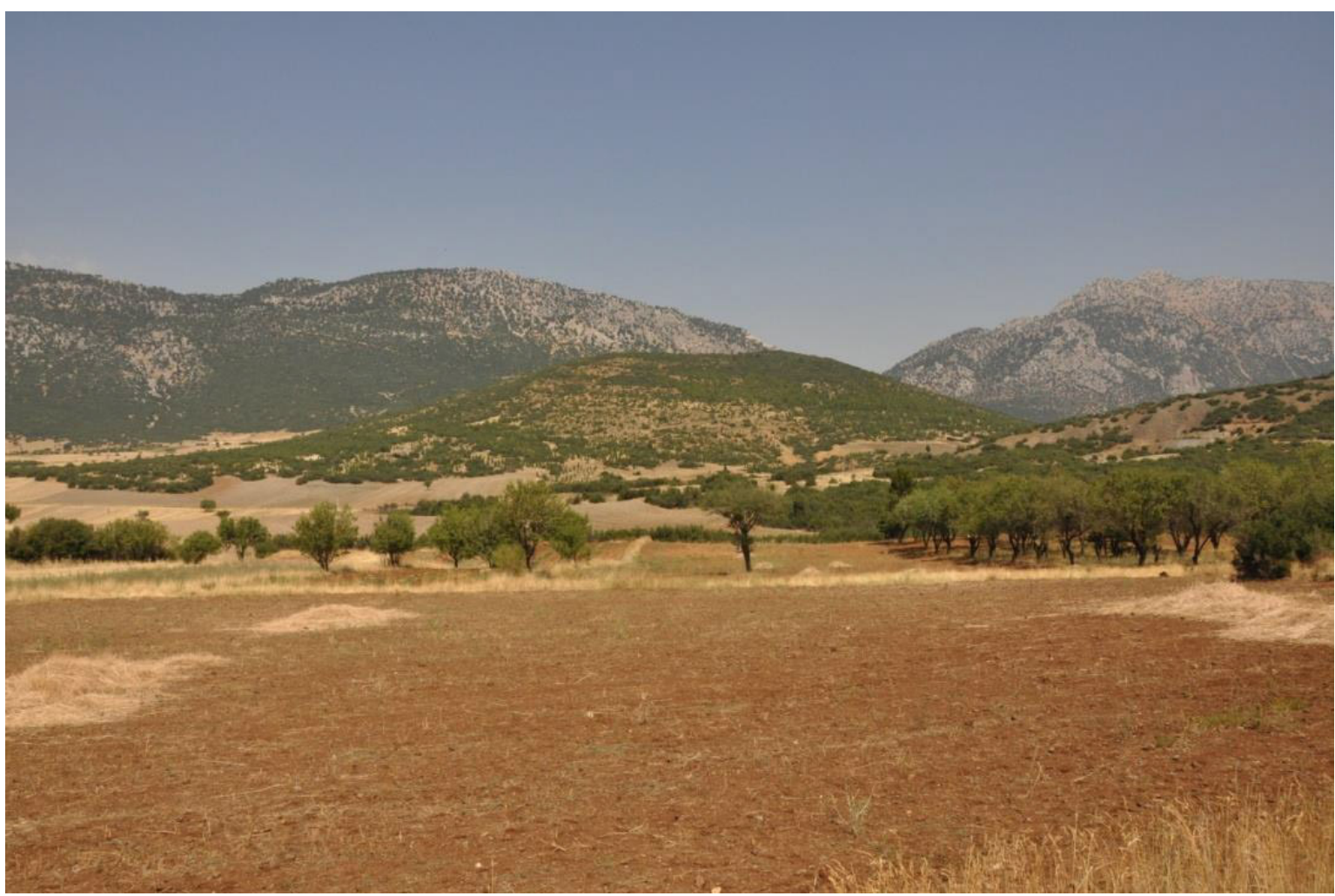

Photo 9: Karstic depression containing red Mediterranean soil and maquis vegetation notably Quercus coccifera on the Mesozoic limestone in the Aziziye locality in the eastern part Katrancik Mountains belonging to Taurus Mountain in the southeast of Burdur Basin

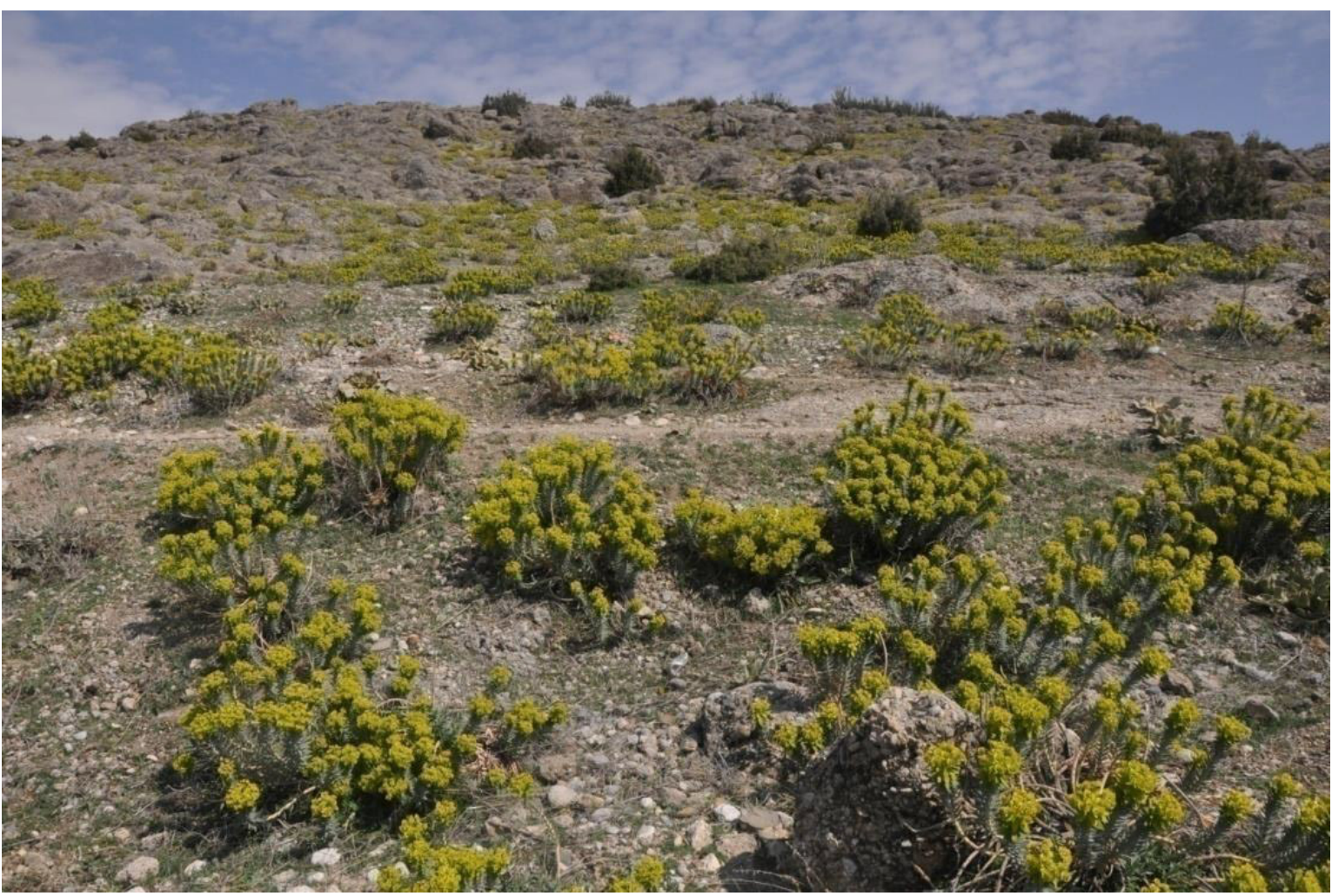

Photo 10: Euphorbia sp community reflecting over grazing on the lithosol that is developed on the conglomerate-sandstone in the NW of Burdur Basin 


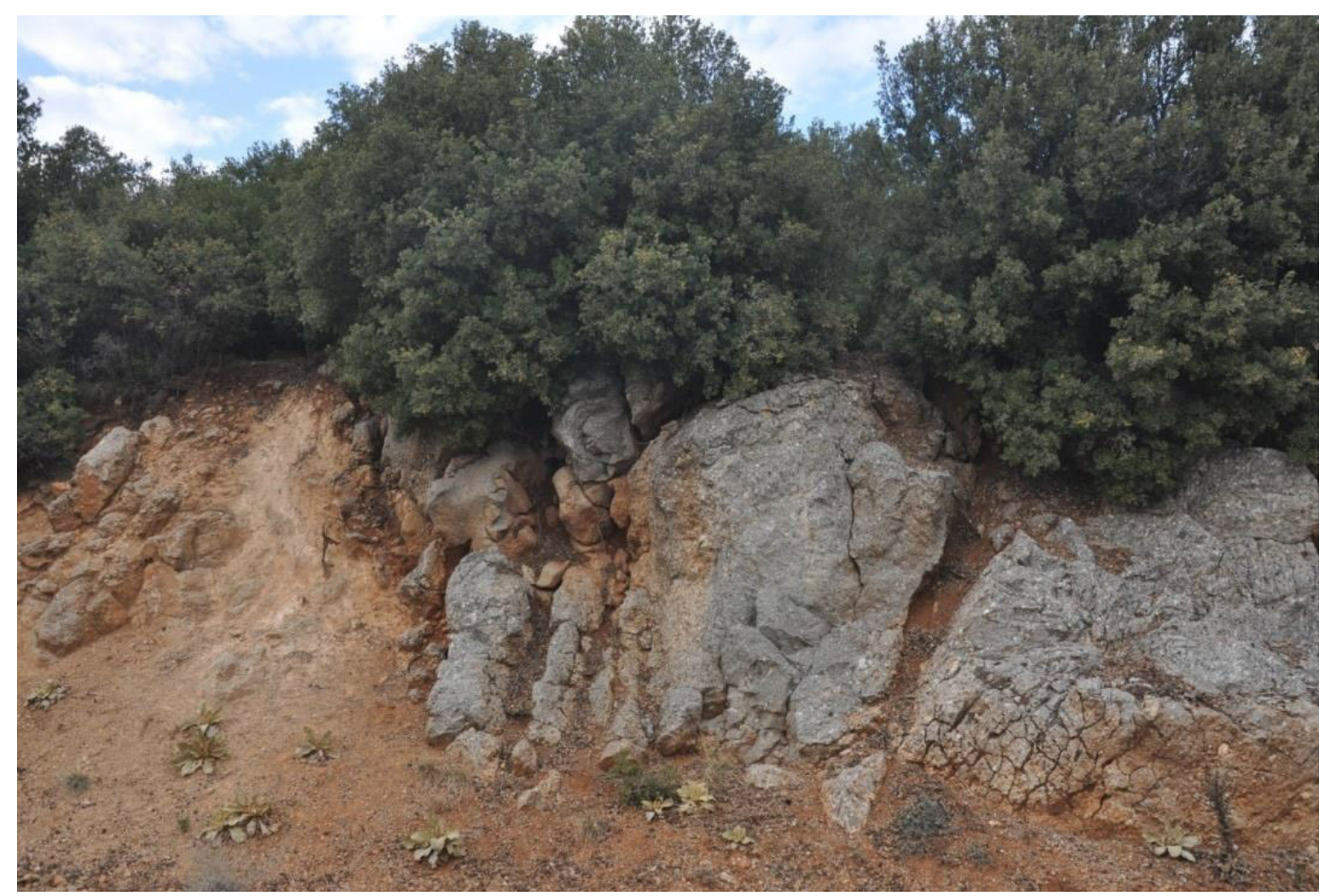

Photo 11: Productive maquis vegetation roots developed along the cracks and soft zone of conglomerate-sandstone in the northern part of Söğüt Mountains

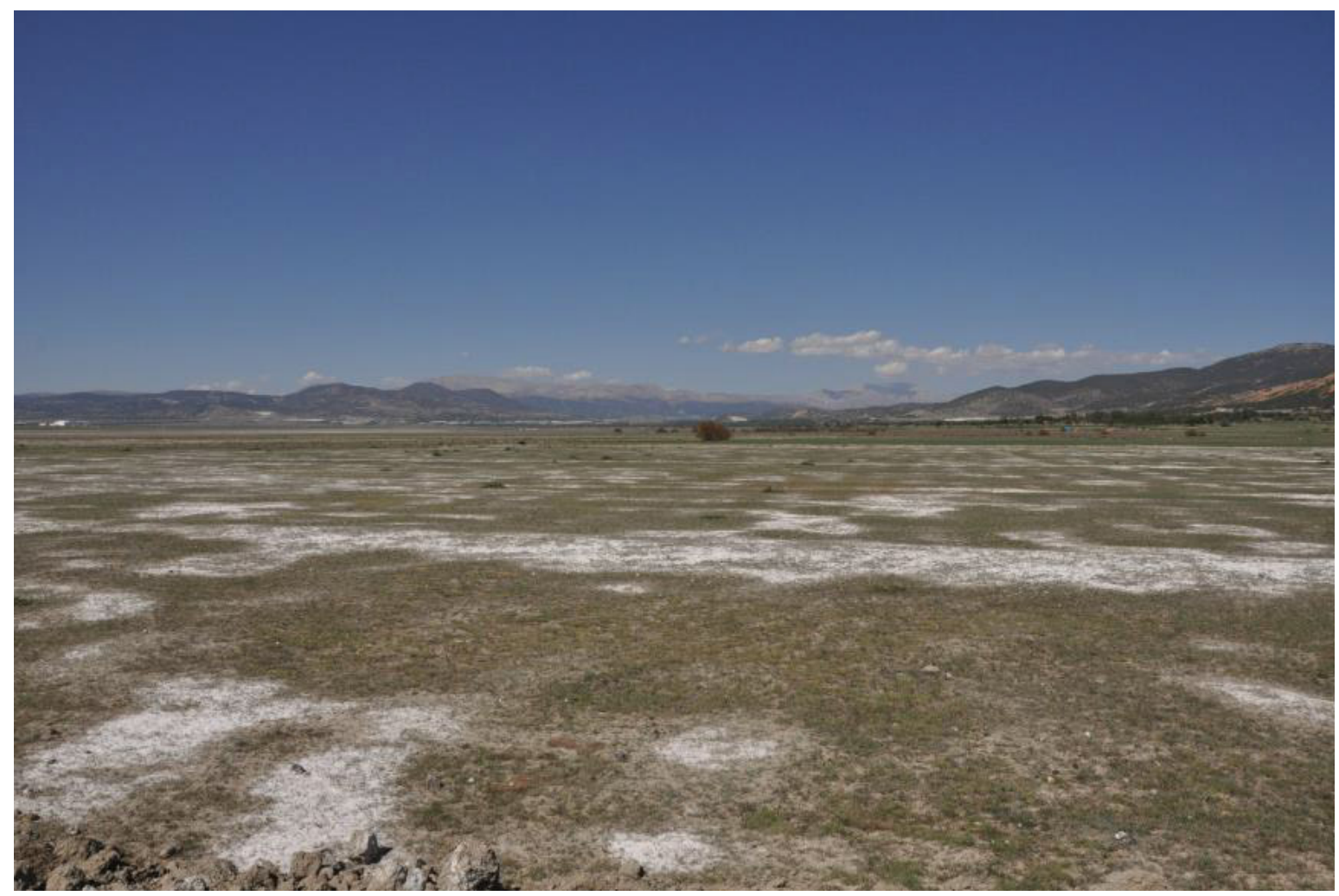

Photo 12: Halobiome containing salt accumulation and sparse hydrophytic vegetation in the northern part of Lake Burdur. 